\title{
Effect of reducing groundwater on the retardation of redox-sensitive radionuclides $\mathrm{QH} \mathrm{Hu}{ }^{* 1}, \mathrm{M}$ Zavarin $^{2}$ and TP Rose ${ }^{2}$
}

Address: ${ }^{1}$ Department of Earth and Environmental Sciences, University of Texas at Arlington, Arlington, TX 76019, USA and ${ }^{2}$ Lawrence Livermore National Laboratory, 7000 East Avenue, MS L-231, Livermore, CA 94550, USA

Email: QH Hu* - maxhu@uta.edu; M Zavarin -zavarin1@llnl.gov; TP Rose - rose23@llnl.gov

* Corresponding author

Published: 12 December 2008

Geochemical Transactions 2008, 9:12 doi:10.1/86/1467-4866-9-12
Received: 21 May 2008

Accepted: 12 December 2008

This article is available from: http://www.geochemicaltransactions.com/content/9/I/I2

(c) 2008 Hu et al; licensee BioMed Central Ltd.

This is an Open Access article distributed under the terms of the Creative Commons Attribution License (http://creativecommons.org/licenses/by/2.0), which permits unrestricted use, distribution, and reproduction in any medium, provided the original work is properly cited.

\begin{abstract}
Laboratory batch sorption experiments were used to investigate variations in the retardation behavior of redox-sensitive radionuclides. Water-rock compositions were designed to simulate subsurface conditions at the Nevada Test Site (NTS), where a suite of radionuclides were deposited as a result of underground nuclear testing. Experimental redox conditions were controlled by varying the oxygen content inside an enclosed glove box and by adding reductants into the testing solutions.

Under atmospheric (oxidizing) conditions, radionuclide distribution coefficients varied with the mineralogic composition of the sorbent and the water chemistry. Under reducing conditions, distribution coefficients showed marked increases for ${ }^{99} \mathrm{Tc}$ (from 1.22 at oxidizing to $378 \mathrm{~mL} / \mathrm{g}$ at mildly reducing conditions) and ${ }^{237} \mathrm{~Np}$ (an increase from 4.6 to $930 \mathrm{~mL} / \mathrm{g}$ ) in devitrified tuff, but much smaller variations in alluvium, carbonate rock, and zeolitic tuff. This effect was particularly important for ${ }^{99} \mathrm{Tc}$, which tends to be mobile under oxidizing conditions. A review of the literature suggests that iodine sorption should decrease under reducing conditions when $\mathrm{I}^{-}$is the predominant species; this was not consistently observed in batch tests. Overall, sorption of $U$ to alluvium, devitrified tuff, and zeolitic tuff under atmospheric conditions was less than in the glove-box tests. However, the mildly reducing conditions achieved here were not likely to result in substantial $\mathrm{U}(\mathrm{VI})$ reduction to U(IV). Sorption of Pu was not affected by the decreasing Eh conditions achieved in this study, as the predominant sorbed Pu species in all conditions was expected to be the low-solubility and strongly sorbing $\mathrm{Pu}(\mathrm{OH})_{4}$.

Depending on the aquifer lithology, the occurrence of reducing conditions along a groundwater flowpath could potentially contribute to the retardation of redox-sensitive radionuclides ${ }^{99} \mathrm{Tc}$ and ${ }^{237} \mathrm{~Np}$, which are commonly identified as long-term dose contributors in the risk assessment in various radionuclide environmental contamination scenarios. The implications for increased sorption of ${ }^{99} \mathrm{Tc}$ and ${ }^{237} \mathrm{~Np}$ to devitrified tuff under reducing conditions are significant as the fractured devitrified tuff serves as important water flow path at the NTS and the horizon for a proposed repository to store high-level nuclear waste at Yucca Mountain.
\end{abstract}




\section{Introduction}

Major sources of radioactive waste and contamination include the production of nuclear fuels for the weapons program and electricity generation, nuclear weapons tests, fuel reprocessing, and nuclear accidents. In the United States, the total volume of all radioactive waste is 5.5 million $\mathrm{m}^{3}$, with a total activity of about $1.2 \times 10^{9} \mathrm{TBq}$ (tera becquerel; $1 \mathrm{TBq}=27.03 \mathrm{Ci}$ ) [1]. In addition, there are large volumes of radiologically contaminated soil (30-80 million $\left.\mathrm{m}^{3}\right)$ and water $\left(1,800-4,700\right.$ million $\left.\mathrm{m}^{3}\right)$, especially at U.S. Department of Energy (DOE) facilities that were used for nuclear weapons production [2]. The Nevada Test Site (NTS) is one such DOE facility, with substantial radiologic contamination resulting from nuclear weapons testing and also the location of the proposed Yucca Mountain geological repository for high-level nuclear waste, which has been the focus of radionuclide transport investigations for more than three decades.

Numerous long-lived radionuclides are present in groundwater at the NTS as a result of 828 underground nuclear weapons tests conducted between 1951 and 1992. When weapons testing ended in September 1992, a total of about $4.9 \times 10^{6} \mathrm{TBq}$ of radioactivity was present in the subsurface [3]. Important radionuclides, in terms of abundance, half-life, environmental mobility, and health effects, include ${ }^{3} \mathrm{H}$ (tritium), ${ }^{14} \mathrm{C}$ (carbon), ${ }^{36} \mathrm{Cl}$ (chlorine), ${ }^{90} \mathrm{Sr}$ (strontium), ${ }^{99} \mathrm{Tc}$ (technetium), ${ }^{129} \mathrm{I}$ (iodine), ${ }^{137} \mathrm{Cs}$ (cesium), ${ }^{237} \mathrm{~Np}$ (neptunium), as well as isotopes of uranium (U), plutonium (Pu), and americium (Am). These radionuclides have been commonly identified as the set of contaminants that would cause risk to human health and the environment within the time frame of interest (1,000 years) for the environmental monitoring program at the NTS [4]. Among them, ${ }^{3} \mathrm{H},{ }^{14} \mathrm{C},{ }^{36} \mathrm{Cl},{ }^{99} \mathrm{Tc}$, and ${ }^{129}$ I presumably have large migration potential due to a minimal interaction with the subsurface media.

The objective of the laboratory study described below is to use batch sorption experiments to investigate the impact of groundwater redox conditions on the mobility of selected radionuclides. Thus far, laboratory sorption data acquired for the radionuclide transport at the NTS has been based upon experiments conducted under atmospheric (oxidizing) conditions mainly because of the simplicity of the tests and the considerations that the NTS has primarily oxidizing groundwaters. While this is also true for most of the radionuclide sorption data available in the literature, biotic or abiotic reductive immobilization of radionuclides ( $U$ in particular) has gained interest in recent years [e.g. $[5,6]]$. For this investigation, we conducted a series of batch studies to evaluate the sorption behavior of redox-sensitive radionuclides (Tc, I, U, Np and $\mathrm{Pu}$ ) under a range of redox conditions spanning those observed in NTS monitoring wells. Some radionuclides that are not redox-sensitive (e.g., $\mathrm{Sr}$ and $\mathrm{Cs}$ ) were also included for comparison. The experiments were conducted using four different types of aquifer materials (alluvium, carbonate rock, devitrified tuff, and zeolitic tuff). Batch sorption experiments were conducted under atmospheric (oxidizing) conditions and in a glove box under five different controlled redox conditions spanning the range from oxidizing to moderately reducing.

\section{Background}

When studying field-scale radionuclide transport, a distribution coefficients $\left(K_{d}\right)$ approach has been commonly employed to quantify the extent of radionuclide-aquifergroundwater interaction. Values of $K_{d}$, a ratio of the sorbed phase concentration to the solution phase concentration at equilibrium, are used in transport simulations to empirically describe radionuclide/aquifer interactions that are the source of retardation for sorbing radionuclides. The $K_{d}$ data are commonly determined from laboratory-scale batch and column experiments under oxidizing conditions [7] or computed by upscaling mechanistic processes [8]. The term sorption is loosely used in this work to describe the concentration decrease in the solution phase of radionuclides, which could include sorption onto the solid as well as surface precipitation.

Table 1 shows the range in measured $K_{d}$ values for eight radionuclides for representative geologic media, including alluvium, carbonate rock, and volcanic tuffs (devitrified, vitric, and zeolitic) encountered at the NTS [4]. Generally speaking, the largest $K_{d}$ values are observed in the zeolitic tuff and in alluvium, and the smallest values in vitric tuff. Sorption of $\mathrm{Pu}$ and Am onto carbonate rock is appreciable, and $\mathrm{Np}$ sorption to carbonate rock is higher than other rock types (Table 1).

The $K_{d}$ values for Tc and I in Table 1 are based on the assumption that pertechnetate $\left(\mathrm{TcO}_{4}{ }^{-}\right)$and iodide $\left(\mathrm{I}^{-}\right)$are the dominant species in groundwater and during experimental measurements [7]. However, these and several of the other radionuclides listed in Table 1 (i.e., Tc, I, Np, U, and $\mathrm{Pu}$ ) are redox-sensitive, and the speciation and retardation of these radionuclides is sensitive to their oxidation state. Variations in groundwater redox conditions, and associated changes in retardation factors are of particular importance to presumably mobile radionuclides, such as ${ }^{9} \mathrm{Tc}$; reducing conditions could result in much longer transport times than those predicted with minimal retardation (i.e., $K_{d}$ close to zero).

\section{Geochemistry and sorption behavior of redox-sensitive radionuclides}

Technetium-99

Technetium exists in valence states ranging from +7 to -1 , but in natural environments, the most stable valence 
Table I: Radionuclide sorption on different rock (compiled from [4])

\begin{tabular}{|c|c|c|c|c|c|c|}
\hline \multirow[t]{2}{*}{ Element } & \multirow[t]{2}{*}{ Sample type } & \multirow[t]{2}{*}{ Number of Samples } & \multicolumn{4}{|c|}{ Distribution Coefficients (mL/g) } \\
\hline & & & Minimum & Maximum & Mean & Standard Deviation \\
\hline \multirow[t]{5}{*}{ Strontium } & Alluvium & 73 & 1 & 781 & 470 & 197 \\
\hline & Carbonate rock & & 5 & 16 & & \\
\hline & Devitrified tuff & 154 & 9 & 1,200 & 101 & $|4|$ \\
\hline & Vitric tuff & 30 & 23 & 220 & 148 & 62 \\
\hline & Zeolitic tuff & 83 & 1,200 & 246,085 & 39,277 & 54,882 \\
\hline \multirow[t]{2}{*}{ Technetium } & Alluvium & 17 & 0 & 12 & 2.16 & 3.48 \\
\hline & All tuffs & & 0 & 0 & & \\
\hline \multirow[t]{2}{*}{ lodine } & Alluvium & 14 & 0 & 24.5 & 5.74 & 4.03 \\
\hline & All tuffs & & 0 & 0 & & \\
\hline \multirow[t]{5}{*}{ Cesium } & Alluvium & 56 & $\mathrm{I}, 720$ & 33,200 & 5,884 & 5,153 \\
\hline & Carbonate rock & & 4 & 101 & & \\
\hline & Devitrified tuff & 159 & 10 & 3,800 & 645 & 656 \\
\hline & Vitric tuff & 30 & 109 & $1,06 \mid$ & 646 & 317 \\
\hline & Zeolitic tuff & 86 & 2,700 & 72,000 & 16,747 & 13,710 \\
\hline \multirow[t]{5}{*}{ Uranium } & Alluvium & 48 & 0.9 & 60 & 6.36 & 5.04 \\
\hline & Carbonate rock & & 0 & 132 & & \\
\hline & Devitrified tuff & 75 & 0 & 15 & 2.51 & 2.29 \\
\hline & Vitric tuff & 59 & 0 & 12 & 1.89 & 1.7 \\
\hline & Zeolitic tuff & 176 & 0 & 9,423 & 45 & 423 \\
\hline \multirow[t]{5}{*}{ Neptunium } & Alluvium & 30 & 1.83 & 22 & 8.57 & 5.08 \\
\hline & Carbonate rock & & $<100$ & 5,000 & & \\
\hline & Devitrified tuff & 421 & 0 & 2,353 & 19 & 166 \\
\hline & Vitric tuff & 400 & 0 & 526 & 3.17 & 29 \\
\hline & Zeolitic tuff & 430 & 0 & 22 & 3 & 2 \\
\hline \multirow[t]{5}{*}{ Plutonium } & Alluvium & 24 & 230 & 21,000 & 4,091 & 4,448 \\
\hline & Carbonate rock & & 100 & 10,000 & & \\
\hline & Devitrified tuff & 118 & 6 & 1,900 & 125 & 168 \\
\hline & Vitric tuff & 71 & 23 & 1,810 & 516 & 472 \\
\hline & Zeolitic tuff & 110 & 19 & 2,000 & 260 & 242 \\
\hline \multirow[t]{5}{*}{ Americium } & Alluvium & 24 & 3,200 & $1,400,000$ & 174,469 & 214,582 \\
\hline & Carbonate rock & & 150 & 300,000 & & \\
\hline & Devitrified tuff & 35 & 79 & 12,000 & 1,845 & $\mathrm{I}, 834$ \\
\hline & Vitric tuff & 8 & 860 & 2,050 & 1,354 & 398 \\
\hline & Zeolitic tuff & 25 & 470 & 33,000 & 5,204 & 7,757 \\
\hline
\end{tabular}

states are +7 and +4 under oxidizing and reducing conditions, respectively. Technetium forms a reduced species [predominantly $\mathrm{Tc}(\mathrm{IV})$ ] at redox potential (Eh) values below about $220 \mathrm{mV}$ with respect to standard hydrogen electrode (SHE) in neutral $\mathrm{pH}$ conditions (Figure 1) [9]. At higher Eh, it occurs as $\mathrm{Tc}(\mathrm{VII}) \mathrm{O}_{4}^{-}$. Due to its weak interaction with mineral surfaces, $\mathrm{TcO}_{4}$ - is considered as one of the most mobile radionuclides in the environment. In contrast, lower-valence $\mathrm{Tc}(\mathrm{IV})$ species [such as $\mathrm{TcO}_{2} \cdot \mathrm{nH}_{2} \mathrm{O}$ with $\mathrm{n}=1-2$; equivalent to $\mathrm{TcO}(\mathrm{OH})_{2}{ }^{\circ}$ in Figure 1 when $\mathrm{n}=1$ ] are expected to be strongly retarded due to their strong sorption and/or precipitation; the solubility of $\mathrm{TcO}_{2} \cdot \mathrm{nH}_{2} \mathrm{O}(\mathrm{s})$ in carbonate-containing groundwater was reported to be about $10^{-8} \mathrm{M}[10,11]$.

The presence of reductants in the host rock (e.g., $\mathrm{Fe}(\mathrm{II})$ in pyrite $\mathrm{FeS}_{2}$ ) can contribute to the reduction of $\mathrm{Tc}(\mathrm{VII})$ to $\mathrm{Tc}(\mathrm{IV})$ [12]. For example, reducing groundwater was observed in boreholes on or near Yucca Mountain, in the western part of the NTS, several of which are known to contain pyrite [13]. Recent work of Hu et al. [14] indicated that the groundwater in the deep NTS aquifer exhibited 


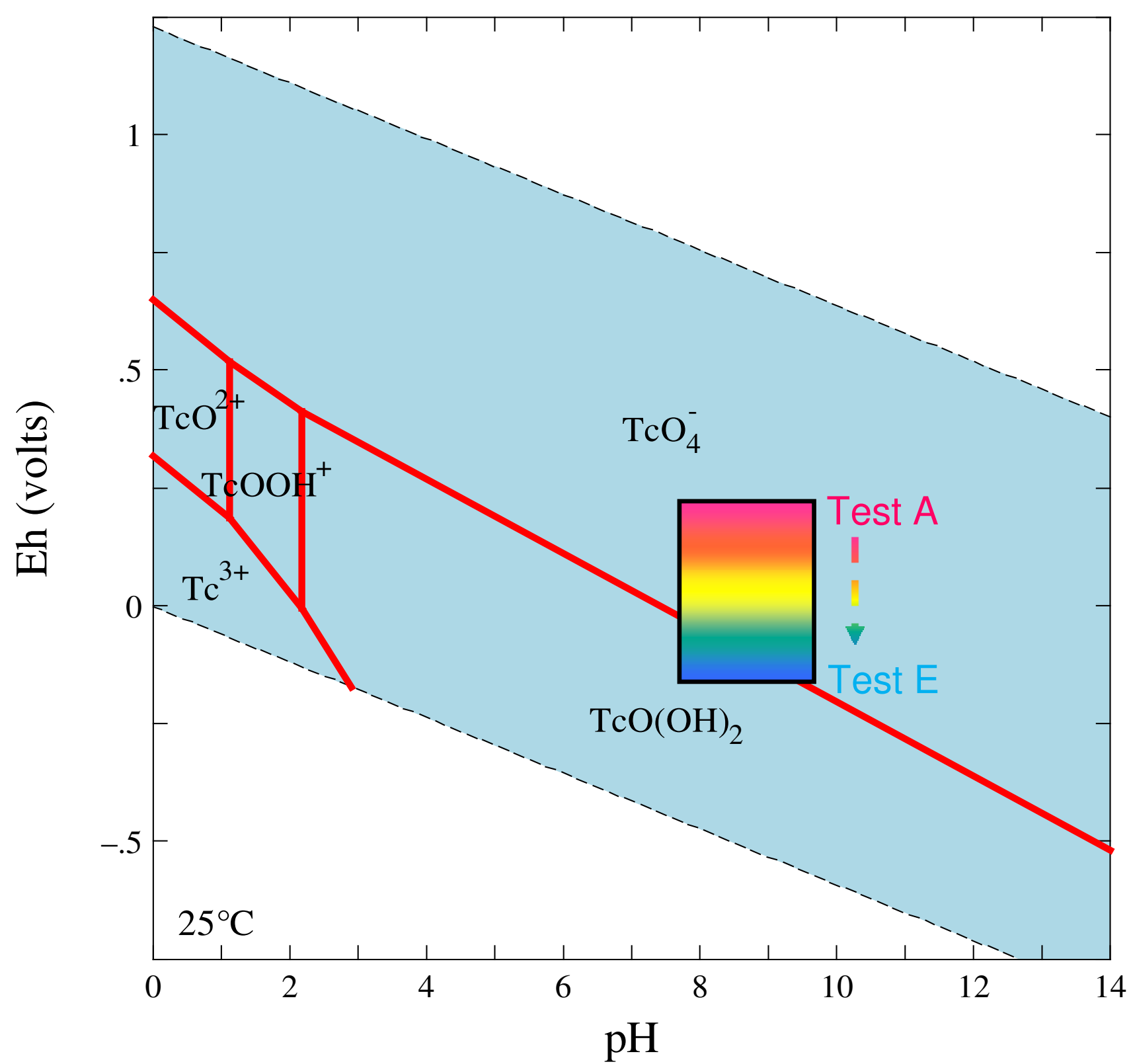

Figure I

Eh-pH diagram drawn at $25^{\circ} \mathrm{C}$ and an equilibrium activity of 10 -1I for technetium; stability fields are shown only for the aqueous species. Diagram was produced using the "thermo" database in the Geochemist's Workbench (version 6.0). Hatched areas are the measured Eh-pH region for Tests A-E conducted in this work.

variable redox conditions. Under reducing conditions, Cui and Eriksen $[15,16]$ reported that $\mathrm{TcO}_{4}^{-}$was reduced to $\mathrm{TcO}_{2} \cdot \mathrm{nH}_{2} \mathrm{O}(\mathrm{s})$ by $\mathrm{Fe}(\mathrm{II})$-bearing fracture-filling minerals on which $\mathrm{Tc}(\mathrm{IV})_{\mathrm{aq}}$ was rapidly sorbed. Reduction of $\mathrm{Tc}(\mathrm{VII})$ to $\mathrm{Tc}(\mathrm{IV})$ occurred with $\mathrm{Fe}(\mathrm{II})$-containing solid phases but not by aqueous Fe(II) species [11,17-19]. Peretyazhko et al. [19] recently demonstrated that mineralassociated $\mathrm{Fe}$ (II) can be an effective heterogeneous reductant of Tc(VII) under anoxic conditions, yielding insoluble
Tc(IV) precipitates, coprecipitates, and/or surface complexes that may significantly retard Tc migration. Their experimental results suggested the following affinity series for heterogeneous $\mathrm{Tc}(\mathrm{VII})$ reduction by $\mathrm{Fe}(\mathrm{II})$ : $\mathrm{Fe}(\mathrm{II})$ adsorbed on $\mathrm{Fe}$ (III) oxides $>>$ structural $\mathrm{Fe}$ (II) in phyllosilicates $\gg$ adsorbed $\mathrm{Fe}(\mathrm{II})$ in phyllosilicates [ionexchangeable and some edge-complexed $\mathrm{Fe}(\mathrm{II})]$ aqueous $\mathrm{Fe}(\mathrm{II})$. 
Lieser and Bauscher [9] observed wide variations in ${ }^{9} \mathrm{Tc}$ distribution coefficients for sediment-water experiments performed under aerobic and anaerobic conditions. By varying the redox potential, they observed a change in the $K_{d}$ by about 3 orders of magnitude within a small range of Eh at $190 \pm 30 \mathrm{mV}$ for a $\mathrm{pH}$ of $7 \pm 0.5$. Chemical equilibrium modeling using EQ3/6 software has also shown the enhanced retardation of ${ }^{99} \mathrm{Tc}$ under reducing conditions in the saturated zone at Yucca Mountain [20]. To summarize, ${ }^{9} \mathrm{Tc}$ can behave as either a non-sorbing species (like chloride) or a strongly sorbing species (like Am) - simply because of a modest change in redox conditions. The assumption that ${ }^{99} \mathrm{Tc}$ will always behave as a mobile species oversimplifies its geochemical behavior and may overestimate its transport rates.

\section{lodine- 129}

The fate and transport of ${ }^{129} \mathrm{I}$ in groundwater is also dictated by its chemical speciation. Aqueous iodine usually occurs as the highly mobile iodide anion $\left(\mathrm{I}^{-}\right)$. Under more oxidizing conditions, iodine will be present as the iodate anion $\left(\mathrm{IO}_{3}^{-}\right)$, which is more reactive than iodide and could be sorbed onto positively-charged sites locally existing in clays and organic matter $[21,22]$. Unlike other redox-sensitive radionuclides (such as ${ }^{9}{ }^{9} \mathrm{Tc}$ ), iodine sorption may decrease under reducing conditions when I- is the predominant species [cf., [23]]. However, coexistence of several iodine species (iodide, iodate, and organic iodine species) has been reported in various aqueous systems, which will tend to make the sorption behavior of iodine more difficult to predict.

\section{Actinides}

A large volume of literature exists on the geochemical behavior of actinides in the environment; topical review papers include Kim [24], Dozol and Hagemann [25], Silva and Nitsche [26], and Kersting and Reimus [27]. In general, the mobility of actinides in aqueous systems is dependent on (1) their thermodynamic properties, which determine solubility and speciation as a function of $\mathrm{pH}$ and redox potential, (2) the availability of inorganic and organic ligands to form soluble complexes, and (3) the composition and abundance of minerals and mineral colloids present in the system. The valence state of redox sensitive radionuclides (including $\mathrm{U}, \mathrm{Np}$ and $\mathrm{Pu}$ ) plays a major role in defining the geochemical reactions and migration behavior of these elements. Solubility-limited concentrations, complexation reactions, sorption onto minerals, and colloid formation all differ considerably as a function of oxidation state [28].

The chemistry of uranium in the environment is dominated by the difference in behavior of the U(IV) and U(VI) ions. The tetravalent form generally has low solubility while the hexavalent form is relatively soluble as the ura- nyl $\left(\mathrm{UO}_{2}{ }^{2+}\right)$ ion and its complexes [29]. As shown in Figure 2, the uranyl ion commonly forms soluble complexes with carbonate ligands at $\mathrm{pH}$ values typical of NTS groundwaters [30,31]. Even at relatively low oxidation potentials, uranyl species may dominate aqueous uranium speciation, although uraninite $\left(\mathrm{UO}_{2}\right)$ is the stable solid phase. Uranium is more readily sorbed onto minerals or organic matter when present as the positively charged uranyl species, and this step may precede reduction to less soluble U(IV) solids [32-35]. However, the strong affinity of carbonate ligands for uranyl [e.g., [36]] in solution effectively competes with sorption, thereby limiting the sorption of uranyl carbonate complexes [28].

An important feature of neptunium chemistry in aqueous systems is the large stability range for $\mathrm{Np}(\mathrm{V})$ [37]. The pentavalent $\mathrm{NpO}_{2}{ }^{+}$species is dominant at $\mathrm{pH}$ values $<8$ whereas $\mathrm{Np}(\mathrm{V})$ carbonate complexes tend to dominate at higher $\mathrm{pH}$ values [28] (Figure 3). Since $\mathrm{Np}(\mathrm{V})$ solid phases are relatively soluble and $\mathrm{Np}(\mathrm{V})$ aqueous species sorb weakly onto common minerals, $\mathrm{Np}(\mathrm{V})$ is relatively mobile in the environment. Under reducing conditions, $\mathrm{Np}(\mathrm{IV})$ is present as the low solubility $\mathrm{Np}(\mathrm{OH})_{4}$ (aq) species at $\mathrm{pH}$ values $>5$ [28]. Np(IV) shows a strong tendency for sorption to mineral surfaces $[37,38]$, which limits its mobility in aqueous systems.

The redox speciation of plutonium is affected by a number of competing variables, and $\mathrm{Pu}$ is observed to coexist in multiple valence states in natural waters [39] (Figure 4; note that the stability fields are shown only for the aqueous species). $\mathrm{Pu}(\mathrm{III})$ and $\mathrm{Pu}(\mathrm{IV})$ tend to be less stable than $\mathrm{Pu}(\mathrm{V})$ and $\mathrm{Pu}(\mathrm{VI})$ under oxidizing, near-neutral $\mathrm{pH}$ conditions, though $\mathrm{Pu}(\mathrm{IV})$ exhibits the strongest tendency to form ligand complexes [40]. The aqueous chemistry of plutonium is further complicated by the fact that $\mathrm{Pu}(\mathrm{IV})$ disproportionates to $\mathrm{Pu}(\mathrm{III})$ and $\mathrm{Pu}(\mathrm{VI})$, $\mathrm{Pu}(\mathrm{V})$ disproportionates to $\mathrm{Pu}(\mathrm{IV})$ and $\mathrm{Pu}(\mathrm{VI})$, and $\mathrm{Pu}(\mathrm{VI})$ is easily reduced $[41,42]$. Kersting and Reimus [27] showed that $\mathrm{Pu}(\mathrm{V})$ reduction to $\mathrm{Pu}(\mathrm{IV})$ is an important mechanism for Pu sorption to mineral surfaces.

Figure 5 summarizes the valence states for several radionuclides as a function of redox potentials, and the figure also includes the expected equilibrium redox potentials associated with the common electron-acceptor couples encountered in groundwater [43]. In the laboratory experiments conducted during this study, the redox conditions were controlled by modifying the oxygen concentration in air, and by spiking the solutions with $\mathrm{Fe}^{2+}$ and $\mathrm{S}^{2-}$.

\section{Experimental methods \\ Materials}

The extent of radionuclide sorption is dependent on the physical and chemical properties of the radionuclide- 


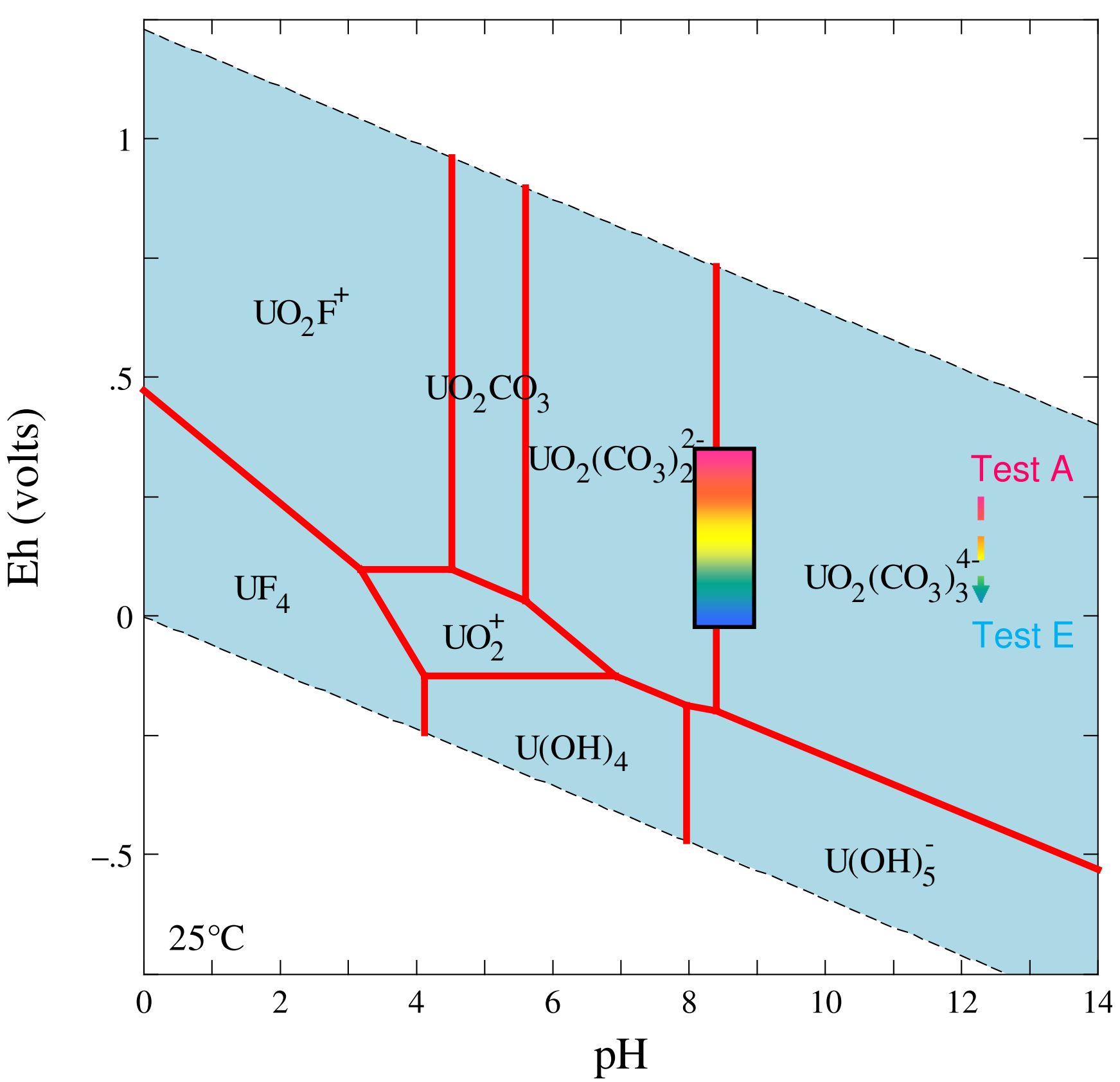

Figure 2

Eh-pH diagrams drawn at $25^{\circ} \mathrm{C}$ and a species activity of $10^{-13} \mathrm{M}$ for uranium in J-13 water.

aquifer-groundwater system. The lithologic (aquifer) materials used in this study included alluvium, welded/ devitrified tuff, zeolitic tuff, and carbonate rock. All lithologic materials were crushed and sieved to a 75-500 $\mu \mathrm{m}$ size range [5]. The alluvium was collected from an exposed section of the U-1a.102 drift in the U-1a tunnel complex (at a depth of $295 \mathrm{~m}$ below the land surface) beneath Yucca Flat. The devitrified tuff sample was a Topopah Spring welded volcanic tuff collected from the
Yucca Mountain tunnel ( $300 \mathrm{~m}$ below ground surface). The original glassy matrix in this material has altered to fine-grained crystalline solids that include feldspar, quartz, cristobalite, and some smectite [44]. The zeolitic tuff sample was from drill core UE-7az (496 m below ground surface) within the tuff confining unit (TCU) of Yucca Flat. Zeolitic tuff is formed by the alteration of glassy vitric tuff near and below the water table [45], and is typically comprised of clinoptilolite $(>60 \%)$, morden- 


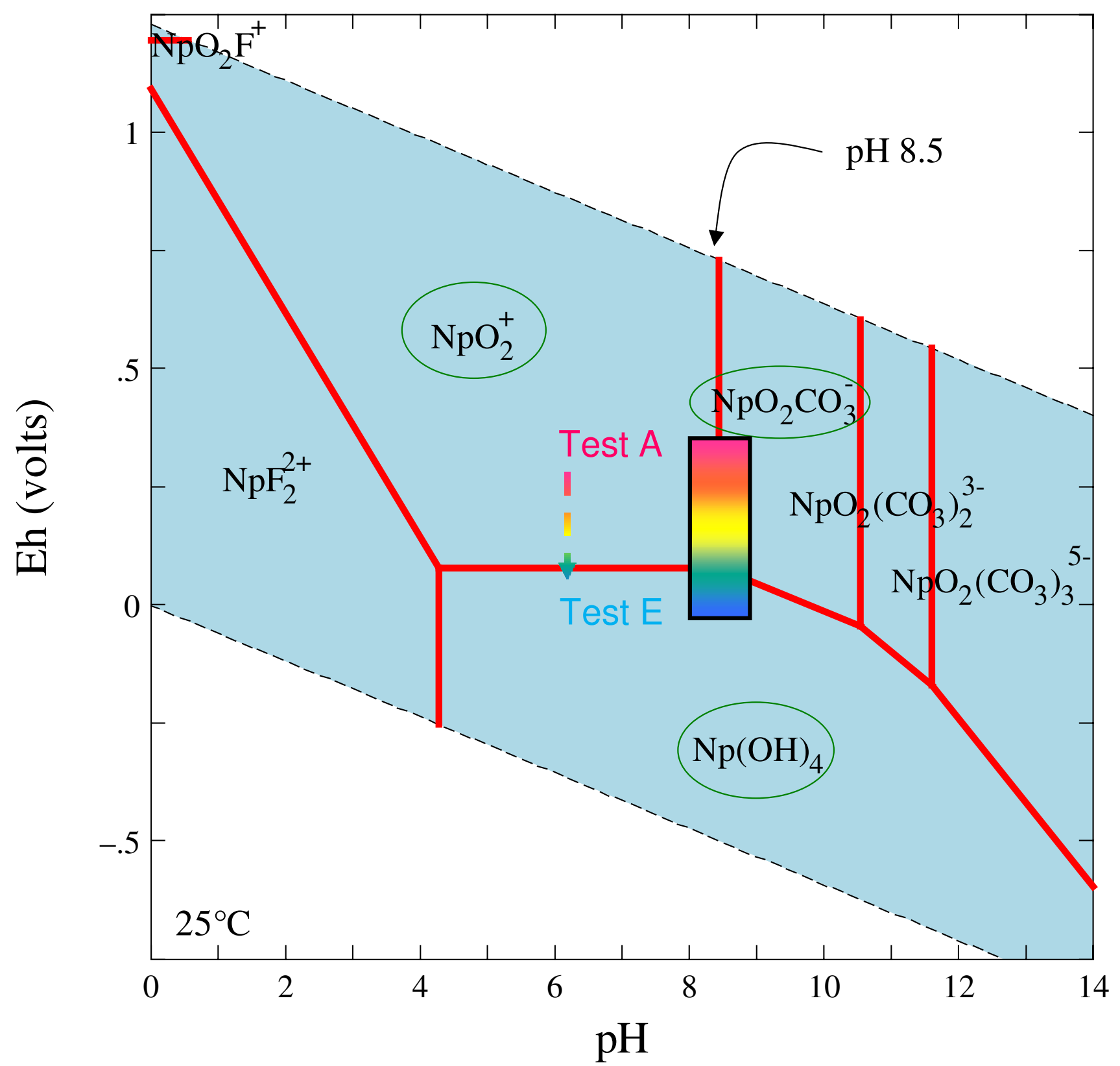

Figure 3

Eh-pH diagrams drawn at $25^{\circ} \mathrm{C}$ and a species activity of $10^{-13} \mathrm{M}$ for neptunium in J-13 water.

ite, opal, feldspar, and quartz. The carbonate rock was from drill core ER-6-1 (833 m below ground surface) within the lower carbonate aquifer (LCA) at Yucca Flat, and consists of massive dolomite with calcite veinlets.

A companion synthetic groundwater was used for each solid matrix. Synthetic LCA (Ca-Mg- $\left.\mathrm{HCO}_{3}\right)$ and TCU (Na$\mathrm{K}-\mathrm{HCO}_{3}$ ) waters were used in carbonate rock and zeolitic tuff sorption experiments, respectively. The solution com- positions were based on measured concentrations of major ions in groundwaters sampled from the respective hydrostratigraphic units, except that sulfate, nitrate, and fluoride were omitted from the background solution because of their minimal role in radionuclide retardation processes. Synthetic J-13 water (Na-K- $\mathrm{HCO}_{3}$ type) was used for the sorption of radionuclides onto alluvium and devitrified tuff. According to the thermodynamic database "thermo" in the Geochemist's Workbench, a solution 


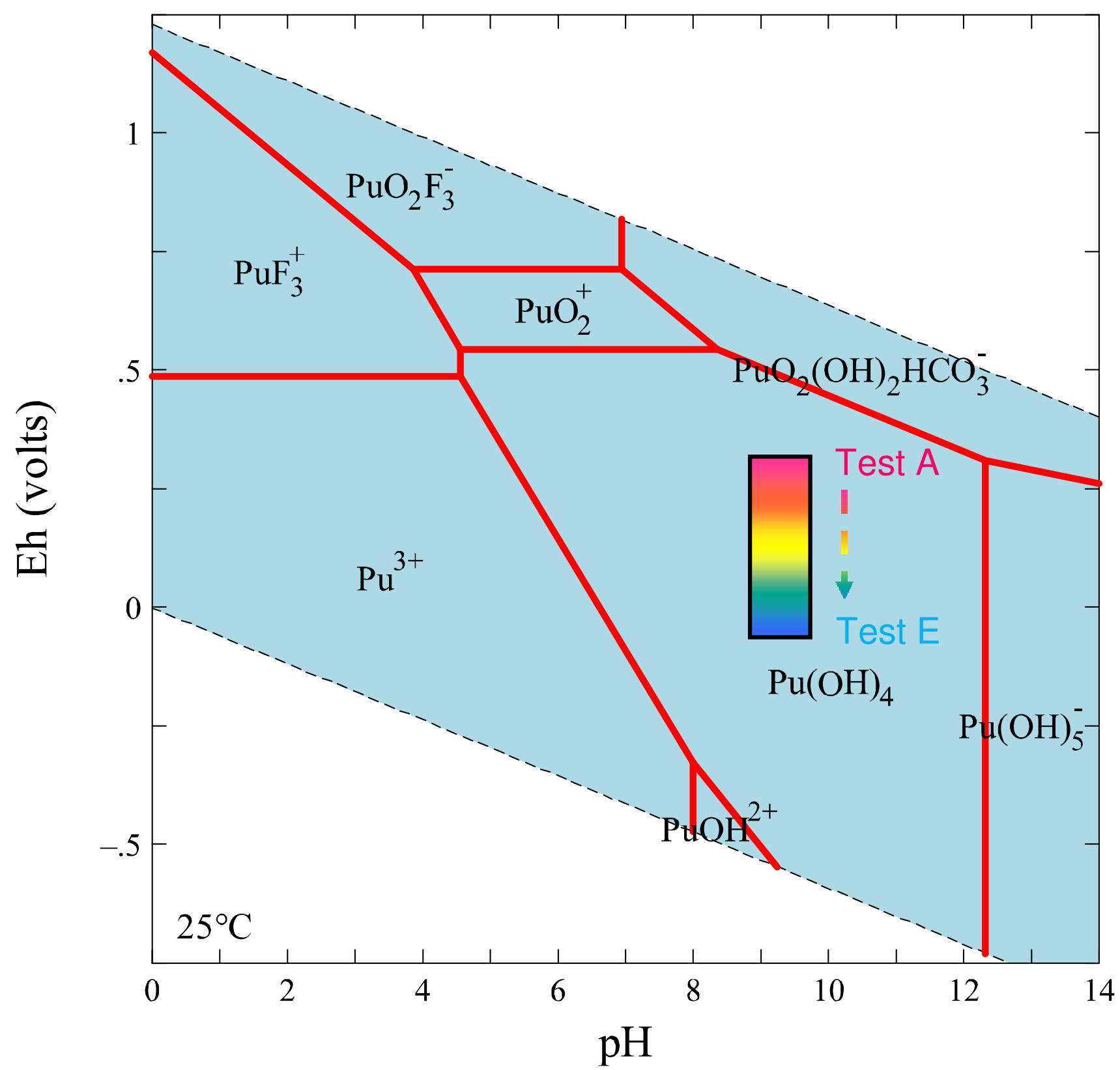

Figure 4

Eh-pH diagrams drawn at $25^{\circ} \mathrm{C}$ and a species activity of $10^{-13} \mathrm{M}$ for plutonium in $\mathrm{J}-13$ water.

composed of J-13 water should be supersaturated with respect to a number of phases, including calcite [46]. To avoid potential mineral precipitation issues, synthetic J13 water was prepared using a recipe from Viani [46] that is predicted to be stable at $25^{\circ} \mathrm{C}$ and atmospheric $p \mathrm{CO}_{2}$. Measured concentrations of constituents in the prepared synthetic background waters are presented in Table 2 .

\section{Reagents}

The radionuclides and surrogate species used in the batchsorption experiments were chosen because they represent a significant fraction of the radiologic source term at the NTS, and are expected to show a wide range of radionuclide retardation behavior. Synthetic groundwaters were spiked with radionuclides and surrogate species at the appropriate amount to achieve the target concentration (Table 3). The target concentration was based on a combi- 


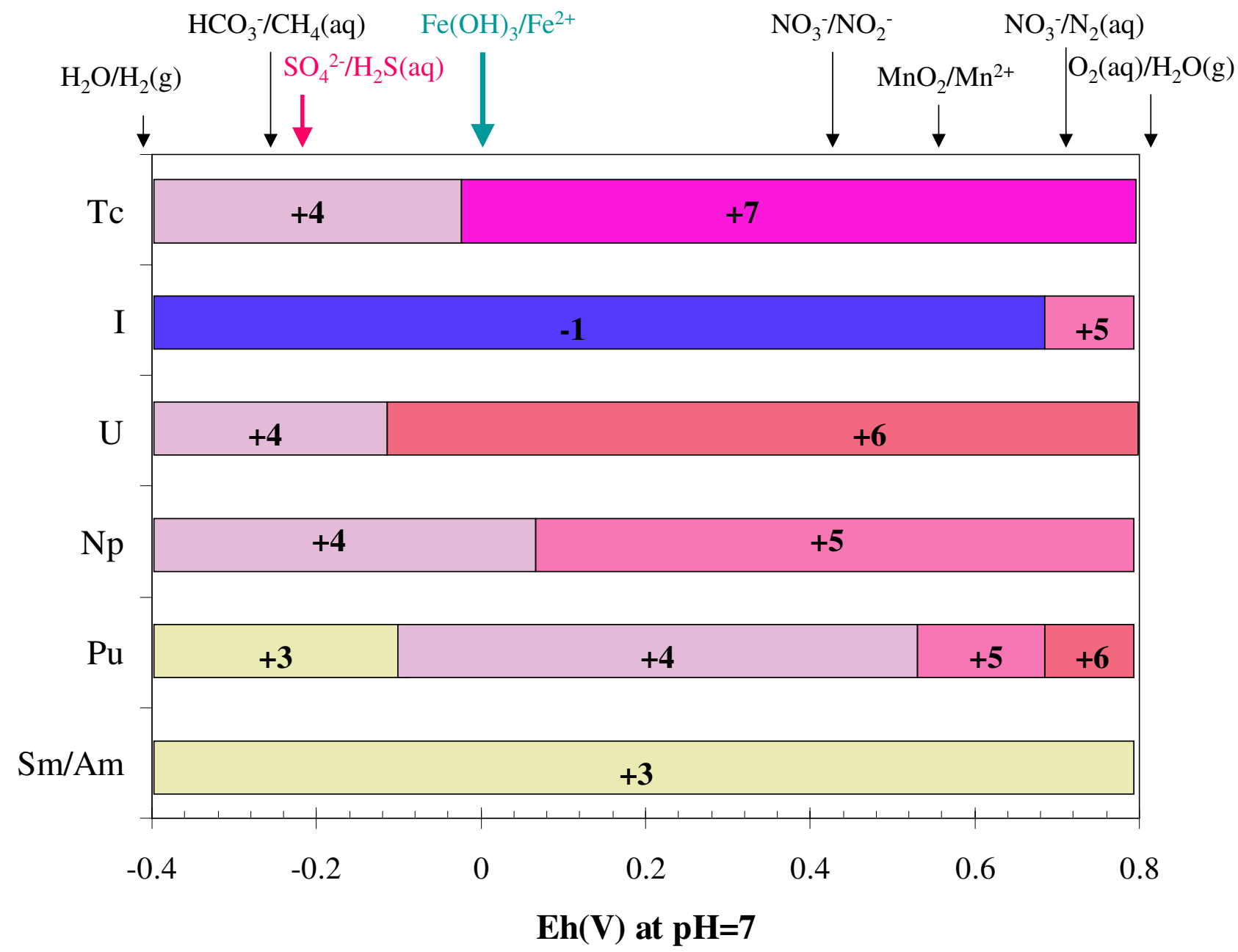

\section{Figure 5}

Expected dominant oxidation states of the radionuclides as a function of standard redox potential under $\mathrm{pH} 7$ in J-I 3 water at equilibrium with atmospheric $\mathbf{C O}_{2}$. Arrows at the top of the figure show the expected redox potentials for common redox couples in the groundwater. This figure was modified from Banaszak et al [43]; results for a $\mathrm{pH} \sim 9$ under which the experiments were conducted in this study will shift the oxidation state boundaries to lower values of Eh.

nation of instrument detection limits, expected background concentrations, and solubility limits. Tables $3 \mathrm{~A}$, $3 \mathrm{~B}$, and $3 \mathrm{C}$ summarize the measured radionuclide compositions of spiked blank solutions. The radionuclide stock solutions $\left({ }^{9}{ }^{9} \mathrm{Tc},{ }^{237} \mathrm{~Np}\right.$, and $\left.\mathrm{Pu}\right)$ were stored in a $\mathrm{HNO}_{3}$ matrix. When spiking samples, a small amount of $\mathrm{NH}_{4} \mathrm{OH}$ was added to minimize $\mathrm{pH}$ changes to solutions.

$\mathrm{U}(\mathrm{VI})$ was assumed to be the dominant $\mathrm{U}$ species in the stock solution based on its stability under oxidizing conditions. The Pu stock solution was purified using a TEVA column. The oxidation state of the Pu stock solution was characterized using both solvent extraction with PMBP (4benzoyl-3-methyl-1-phenyl-2-pyrozolln-5-one) as described in [47-50] and Pu co-precipitation by lanthanum fluoride [51]. The results indicated that the Pu stock solution consisted of $80 \% \mathrm{Pu}(\mathrm{IV}), 15 \% \mathrm{Pu}(\mathrm{III})$ and $5 \%$ colloidal Pu. The ${ }^{237} \mathrm{~Np}$ stock was purified in concentrated $\mathrm{HCl}$ with KI solid using an AG1 × 8 (100-200 mesh) resin column. The $\mathrm{Np}$ was eluted from the column using $0.1 \mathrm{M}$ $\mathrm{HNO}_{3}$. The Np solution was dried in $\mathrm{HNO}_{3}$ on a hotplate before re-dissolving in $1 \mathrm{M} \mathrm{HCl}$ to make a $\mathrm{Np}(\mathrm{V})$ solution. $\mathrm{Np}(\mathrm{V})$ oxidation state of the stock solution was confirmed by UV/VIS spectrometry.

Chemical forms used in the initial solution were $\mathrm{Sr}^{2+}, \mathrm{Cs}^{+}$, $\mathrm{I}^{-},{ }^{9} \mathrm{TcO}_{4}^{-}$, and $\mathrm{ReO}_{4}-$. Valence states for the actinides were $\mathrm{U}(\mathrm{VI}),{ }^{237} \mathrm{~Np}(\mathrm{~V})$, and $\mathrm{Pu}(\mathrm{IV})$; the predominant chemical forms are expected to be carbonate and/or hydroxide complexes for $\mathrm{U}, \mathrm{Np}$, and $\mathrm{Pu}$. These are the valence states and chemical forms expected to occur in the oxidizing groundwaters at the NTS. Cs and Sr are not subject to 
Table 2: Chemical composition ( $\mathrm{mg} / \mathrm{L})$ of background solutions

\begin{tabular}{cccc}
\hline Constituent & J-13 & LCA & TCU \\
\hline Calcium & 3.04 & 50.33 & 1.02 \\
Magnesium & 1.34 & 42.6 & 0.336 \\
Potassium & 4.36 & 22.2 & 6.608 \\
Silicon & 18.6 & & \\
Sodium & 37.7 & 109 & 76.8 \\
Bicarbonate & 99.4 & $447 \mathrm{a}$ & 225 \\
Chloride & 4.16 & 142 & 14.4 \\
Fluoride & 1.13 & & \\
Nitrate & 3.26 & & \\
Sulfate & 10.2 & & \\
pH (unitless) & 7.98 & 8.08 & 8.88 \\
\hline
\end{tabular}

a Estimated from the charge balance.

changes in oxidation state and were included for comparison. $\mathrm{ReO}_{4}{ }^{-}$is sometimes used as the surrogate for $\mathrm{TcO}_{4}{ }^{-}$ based on their similar crystal chemistry, electronic configuration, and thermodynamic data [52-54]. However, there is a difference between Re and Tc in their respective oxidation potentials. A comparison of the $\mathrm{E}_{\mathrm{h}}-\mathrm{pH}$ diagrams for $\mathrm{Re}$ and $\mathrm{Tc}$ shows that $\mathrm{ReO}_{4}^{-}$is in equilibrium with $\mathrm{ReO}_{3}$ and $\mathrm{Re}_{2} \mathrm{O}_{3}$ over a wide range of conditions. In contrast, there are no equilibrium fields for $\mathrm{TcO}_{3}$ or $\mathrm{Tc}_{2} \mathrm{O}_{3}$ [55]. Furthermore, the reduction of Re from +7 to +4 is more difficult than for Tc [55-57].

Radionuclides $\mathrm{Pu}$ and ${ }^{237} \mathrm{~Np}$ used in the batch sorption solutions were from existing stocks at Lawrence Livermore National Laboratory. Standard Reference Materials, SRM 4288A for ${ }^{9} \mathrm{~T}$ Tc, SRM 4341 for ${ }^{237} \mathrm{~Np}$, and SRM $4334 \mathrm{H}$ for ${ }^{242} \mathrm{Pu}$, obtained from the National Institute of Standards and Technology, were used to prepare the standard solution to calibrate the ICP-MS instrument for measuring the radionuclide concentrations in the batch-sorption samples.

\section{Experimental procedure}

The first batch test (Test A in Table 3) was carried out under atmospheric conditions. The test was conducted in accordance with ASTM method D4646 [58], except that a solution to solid ratio of 5:1 (one gram of air-dry solid to $5 \mathrm{~mL}$ of sorption solution) was employed instead of the 20:1 ratio specified in the ASTM method. All sorption treatments (solid and sorption solution) were run in triplicate. Blank (solid and background solution) and control (no solid; only sorption solution) treatments were run in duplicate.

A $0.7 \mathrm{~m}^{3}$ glove box was used to modify and control the atmospheric composition for the other batch sorption experiments (Tests B-E). Either high purity Ar or a mixture of $99 \% \mathrm{Ar}$ and $1 \% \mathrm{CO}_{2}$ was used to control the atmosphere composition inside the glove box. Tests $\mathrm{B}$ and $\mathrm{C}$ were conducted under a gas composition of about 1 and $0.1 \% \mathrm{O}_{2}$, controlled by maintaining the flow rate (pressure) of the pure Ar gas. Tests D and E were all conducted at $0.1 \% \mathrm{O}_{2}$ level, with test tubes further spiked with a reductant $\left(\mathrm{FeCl}_{2}\right.$ for Test $\mathrm{D}$ or $\mathrm{Na}_{2} \mathrm{~S}$ for Test $\left.\mathrm{E}\right)$ (Table 3 ). Two gas sensors were placed inside the glove box to monitor air composition. The oxygen sensor (Pro $\mathrm{O}_{2}$ analyzer, Nuvair Gas Analyzers, Oxnard, CA) has a detection limit of $0.1 \% \mathrm{O}_{2}$. A CO $2 /$ temperature sensor (Model 7001, Telaire, Goleta, CA) was used to monitor the concomitant decrease of $\mathrm{CO}_{2}$ with $\mathrm{O}_{2}$ and to confirm the decreased $\mathrm{O}_{2}$ level inside the glove box. The $\mathrm{CO}_{2}$ sensor (working range of $\sim 400$ to $1 \mathrm{ppm}$ ) is more sensitive than the $\mathrm{O}_{2}$ sensor (working range of 21 to $0.1 \%$ ). The experimental temperature was $22.9 \pm 0.5^{\circ} \mathrm{C}$.

During the sorption experiments conducted inside the glove box, 15-mL sized centrifuge tubes were uncovered to permit gas exchange and placed on a shaker (Maxi-Mix III type 65800, Thermolyne, Dubuque, IA) at a shaker speed of $1,000 \mathrm{rpm}$. Batch tests were started when the $\mathrm{O}_{2}$ level inside the glove box reached steady-state levels, usually after flushing for 2-4 hours. Then after 48 hours, batch sorption tests were stopped and the sample was filtered with a $0.2 \mu \mathrm{m}$ PTFE membrane syringe filter (Acrodisc CR $13 \mathrm{~mm}$, Pall Life Sciences, East Hills, NY). The sorption kinetics of radionuclides and the limited mixing during sorption experiments was not evaluated, as this study was intended to compare the effects of redox conditions on sorption under otherwise similar experimental conditions. Furthermore, redox reactions can be kinetically limited, requiring timescales on the order of weeks to achieve steady state [59]. Consequently, observations at 48 hours may not capture the full extent of the redox manipulation. Comparative effects between samples at 48 hours address the initial response of radionuclides to abrupt redox changes.

An aliquot of filtrate $(0.5 \mathrm{~mL})$ was pipetted into $3.5 \mathrm{~mL}$ $2 \% \mathrm{HNO}_{3}$ solution for subsequent ICP-MS (Thermo Electron Model X7, Thermo Fisher Scientific, Inc, Waltham, MA) analysis of all elements of interest; $5 \mathrm{ng} / \mathrm{L}$ of ${ }^{6} \mathrm{Li},{ }^{45} \mathrm{Sc}$, ${ }^{115} \mathrm{In}$, and ${ }^{209} \mathrm{Bi}$ were included as internal standards. The redox potential, relative to the standard hydrogen electrode, was measured using platinum as a sensing electrode and silver-silver chloride as a reference electrode (Thermo Orion Eh combination electrode, model 9678BN, Thermo Fisher Scientific, Inc, Waltham, MA) filled with saturated potassium chloride. Standard Zobell's solution (a solution of potassium ferric-ferrocyanide of known Eh) was used to verify the working operation of the measurement system [60]. Measurement of $\mathrm{pH}$ for the filtrate was conducted using an Oakton meter (Eutech Instruments, Singapore) and glass $\mathrm{pH}$ electrode system (Orion Ross combination $\mathrm{pH}$ electrode, model 81-02) calibrated to 
Table 3: The measured radionuclide compositions of spiked blank solutions

\begin{tabular}{|c|c|c|c|c|c|c|c|c|c|}
\hline \multicolumn{10}{|c|}{ A. Measured initial radionuclide concentrations $(\mu \mathrm{g} / \mathrm{L})$ in synthetic J-13 water } \\
\hline Test ID & $\begin{array}{c}\text { Test } \\
\text { Condition }\end{array}$ & Sr & Tc-99 & $\mathbf{I}$ & Cs & $\mathbf{R e}$ & Np-237 & $\mathbf{U}$ & Pu-242 \\
\hline \multirow[t]{2}{*}{ A } & atm & $3648 \pm 117$ & 9.88 & $\begin{array}{c}12764 \pm \\
1137\end{array}$ & $1112 \pm 38.5$ & $159 \pm 5.09$ & $199 \pm 5.66$ & $1192 \pm 36.2$ & $\begin{array}{c}0.0785 \pm \\
0.004\end{array}$ \\
\hline & & $\left(4.16 \times 10^{-5}\right)^{\mathrm{a}}$ & $\left(9.99 \times 10^{-8}\right)$ & $\left(1.01 \times 10^{-4}\right)$ & $\left(8.37 \times 10^{-6}\right)$ & $\left(8.54 \times 10^{-7}\right)$ & $\left(8.39 \times 10^{-7}\right)$ & $\left(5.01 \times 10^{-6}\right)$ & $\left(3.24 \times 10^{-10}\right)$ \\
\hline B & $1 \% \mathrm{O}_{2}$ & $4695 \pm 9.62$ & $12.7 \pm 0.06$ & $19116 \pm 62.2$ & $1469 \pm 0.57$ & $209 \pm 1.36$ & $261 \pm 1.19$ & $1118 \pm 34.5$ & $\begin{array}{l}0.113 \pm \\
0.0001\end{array}$ \\
\hline C & $0.1 \% \mathrm{O}_{2}$ & $4598 \pm 11.3$ & $12.4 \pm 0.00$ & $18616 \pm 679$ & $1439 \pm 2.26$ & $204 \pm 0.40$ & $258 \pm 0.06$ & $1518 \pm 11.3$ & $\begin{array}{c}0.111 \pm \\
0.017\end{array}$ \\
\hline $\mathrm{D}$ & II ppm $\mathrm{FeCl}_{2}$ & $3190 \pm 162$ & $8.91 \pm 0.29$ & $207| \pm 48|$ & $993 \pm 40.7$ & $|5| \pm 4.53$ & $148 \pm 6.62$ & $393 \pm 477$ & $\begin{array}{c}0.032 \pm \\
0.036\end{array}$ \\
\hline $\mathrm{E}$ & $24 \mathrm{ppm} \mathrm{Na} \mathrm{N}_{2} \mathrm{~S}$ & $3134 \pm 50.9$ & $8.63 \pm 0.12$ & $1090 \pm 0.00$ & $986 \pm 44.1$ & $159 \pm 19.1$ & $162 \pm 21.0$ & $656 \pm 268$ & $\begin{array}{c}0.030 \pm \\
0.023\end{array}$ \\
\hline Method c & etection limit & 0.1 & 0.005 & 20 & 0.2 & 0.02 & 0.002 & 0.05 & 0.0005 \\
\hline
\end{tabular}

a Average concentration $(\mathrm{mol} / \mathrm{L})$ in parentheses.

B. Measured initial radionuclide concentrations $(\mu \mathrm{g} / \mathrm{L})$ in synthetic LCA water

\begin{tabular}{|c|c|c|c|c|c|c|c|c|c|}
\hline Test ID & $\begin{array}{c}\text { Test } \\
\text { Condition }\end{array}$ & Sr & Tc-99 & $\mathbf{I}$ & Cs & $\mathbf{R e}$ & Np-237 & $\mathbf{u}$ & Pu-242 \\
\hline$A$ & atm & $3630 \pm 246$ & $9.56 \pm 0.61$ & $11900 \pm 990$ & $1109 \pm 78.6$ & $159 \pm 11.0$ & $200 \pm 1.48$ & $1202 \pm 91.6$ & $\begin{array}{c}0.100 \pm \\
0.008\end{array}$ \\
\hline B & $1 \% \mathrm{O}_{2}$ & $4724 \pm 76.4$ & $12.4 \pm 0.27$ & $18516 \pm 84.8$ & $1473 \pm 25.5$ & $206 \pm 4.41$ & $262 \pm 3.56$ & $1587 \pm 25.5$ & $\begin{array}{c}0.136 \pm \\
0.001\end{array}$ \\
\hline $\mathrm{C}$ & $0.1 \% \mathrm{O}_{2}$ & $4629 \pm 2.26$ & $12.3 \pm 0.00$ & $19276 \pm 119$ & $1437 \pm 9.05$ & $204 \pm 0.45$ & $260 \pm 0.11$ & $1556 \pm 2.83$ & $\begin{array}{l}0.133 \pm \\
0.0002\end{array}$ \\
\hline $\mathrm{D}$ & II ppm $\mathrm{FeCl}_{2}$ & $3656 \pm 522$ & $9.72 \pm 1.39$ & $1968 \pm 87.7$ & $1099 \pm 158$ & $162 \pm 23.1$ & $139 \pm 21.0$ & $62.1 \pm 81.0$ & $\begin{array}{c}0.008 \pm \\
0.008\end{array}$ \\
\hline $\mathrm{E}$ & $24 \mathrm{ppm} \mathrm{Na} \mathrm{N}_{2} \mathrm{~S}$ & $3182 \pm 83.2$ & $8.53 \pm 0.19$ & $846 \pm 7.35$ & 966 & $144 \pm 4.36$ & $144 \pm 5.32$ & $207 \pm 52.1$ & $\begin{array}{c}0.011 \pm \\
0.006\end{array}$ \\
\hline
\end{tabular}

C. Measured initial radionuclide concentrations $(\mu \mathrm{g} / \mathrm{L})$ in synthetic TCU water

\begin{tabular}{|c|c|c|c|c|c|c|c|c|c|}
\hline Test ID & $\begin{array}{c}\text { Test } \\
\text { Condition }\end{array}$ & Sr & Tc-99 & $\mathbf{I}$ & Cs & $\mathbf{R e}$ & Np-237 & $\mathbf{U}$ & Pu-242 \\
\hline A & atm & $3786 \pm 3.39$ & $9.88 \pm 0.02$ & $12252 \pm 28.3$ & $1166 \pm 7.92$ & $163 \pm 0.45$ & $207 \pm 0.34$ & $1252 \pm 0.57$ & $\begin{array}{l}0.106 \pm \\
0.0004\end{array}$ \\
\hline B & $1 \% \mathrm{O}_{2}$ & $4720 \pm 41.9$ & $12.7 \pm 0.06$ & $20788 \pm 73.5$ & $1483 \pm 11.3$ & $211 \pm 1.19$ & $266 \pm 3.73$ & $1114 \pm 19.2$ & $\begin{array}{c}0.135 \pm \\
0.003\end{array}$ \\
\hline C & $0.1 \% \mathrm{O}_{2}$ & $4601 \pm 0.00$ & $12.1 \pm 0.01$ & $18152 \pm 67.9$ & $1434 \pm 2.26$ & $200 \pm 0.40$ & $256 \pm 2.66$ & $1549 \pm 11.9$ & $\begin{array}{c}0.134 \pm \\
0.002\end{array}$ \\
\hline $\mathrm{D}$ & II ppm $\mathrm{FeCl}_{2}$ & $3149 \pm 24.3$ & $8.39 \pm 0.04$ & $1896 \pm 301$ & $957 \pm 10.8$ & $|4| \pm 0.74$ & $98.6 \pm 33.1$ & $962 \pm 33.9$ & $\begin{array}{c}0.037 \pm \\
0.042\end{array}$ \\
\hline$E$ & $24 \mathrm{ppm} \mathrm{Na} 2 \mathrm{~S}$ & $3174 \pm 215$ & $8.54 \pm 0.57$ & $946 \pm 46.4$ & $1018 \pm 22.6$ & $180 \pm 32.8$ & $190 \pm 44.3$ & $1374 \pm 314$ & $\begin{array}{c}0.107 \pm \\
0.007\end{array}$ \\
\hline
\end{tabular}

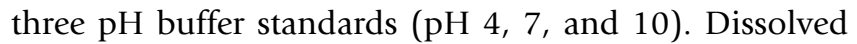
oxygen in the filtrate was evaluated with a SympHony SB50D (Thermo Orion) with a detection limit of $0.1 \mathrm{mg} /$ L. All these measurements, except for ICP-MS analyses, were performed inside the glove box under the desired $\mathrm{O}_{2}$ level.
Evaluation of redox conditions

The principal redox couples in the subsurface are $\mathrm{O}_{2} / \mathrm{H}_{2} \mathrm{O}$, $\mathrm{NO}_{3}-/ \mathrm{N}_{2}, \mathrm{Mn}(\mathrm{IV}, \mathrm{III}) / \mathrm{Mn}(\mathrm{II}), \mathrm{Fe}(\mathrm{III}) / \mathrm{Fe}(\mathrm{II}), \mathrm{SO}_{4}^{2-} / \mathrm{H}_{2} \mathrm{~S}$, and $\mathrm{CO}_{2} / \mathrm{CH}_{4}$, which form a redox ladder from the most oxidizing $\mathrm{O}_{2} / \mathrm{H}_{2} \mathrm{O}$ to the reducing $\mathrm{CO}_{2} / \mathrm{CH}_{4}$ couples. The theoretical (thermodynamically calculated) Eh values at 


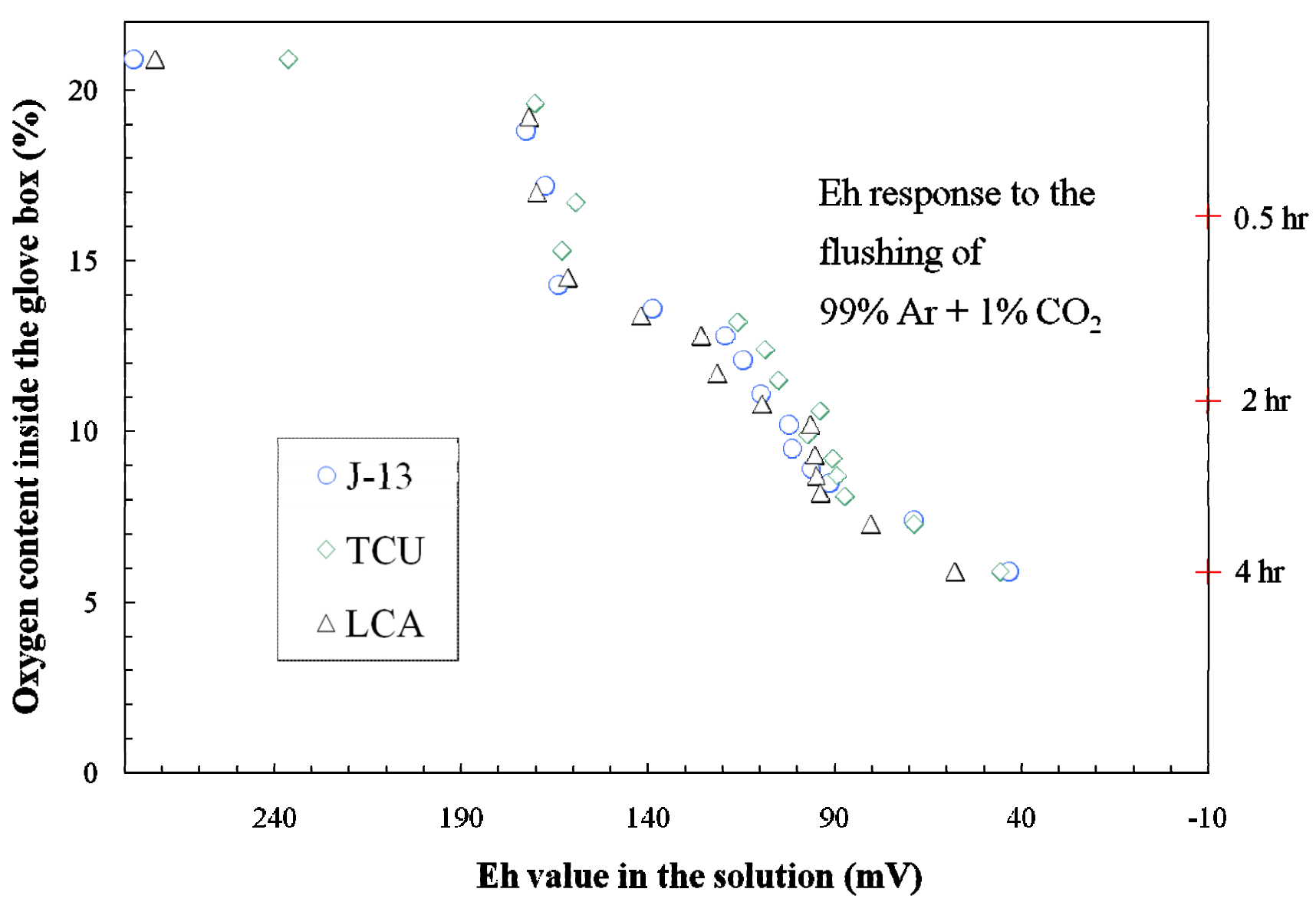

Figure 6

Change of solution Eh in response to the gas composition ( $99 \% \mathrm{Ar}$ and $\left.\mathrm{I} \% \mathrm{CO}_{2}\right)$ inside the glove box for three different background solutions.

pH 7 are $816,-182$, and $-215 \mathrm{mV}$ for the $\mathrm{O}_{2} / \mathrm{H}_{2} \mathrm{O}, \mathrm{Fe}(\mathrm{III}) /$ $\mathrm{Fe}(\mathrm{II})$, and $\mathrm{SO}_{4}{ }^{2-} / \mathrm{H}_{2} \mathrm{~S}$ redox couples employed in this study. However, various authors suggest caution in using Eh to quantify redox condition $[61,62]$. The difficulty in interpreting redox from Eh measurements results from using an equilibrium approach to describe a highly dynamic system [63]. Eh is a simple measure, but it gives at best only qualitative assessment of water redox conditions because the Pt electrode may not respond to many important redox couples [64]. Thus, a wide range of Eh has been observed for the same redox couple and, as a result, several redox reactions may be relevant within the same Eh range [64]. The measured Eh usually reflects "non-equilibrium" potentials and can only be qualitatively interpreted. Supplementary measurements of redox couple concentrations should be made in addition to Eh measurements to better evaluate redox conditions.

In this work, Eh values measured with a platinum electrode did not appear to reflect the Eh difference between the $\mathrm{SO}_{4}{ }^{2-} / \mathrm{H}_{2} \mathrm{~S}$ and $\mathrm{Fe}(\mathrm{III}) / \mathrm{Fe}(\mathrm{II})$ redox couples. In addi- tion to the Eh measurements, sulfate production in the sulfate/sulfide redox couple was monitored. In Test $\mathrm{E}$ where $24 \mathrm{mg} / \mathrm{L}(0.3 \mathrm{mM}) \mathrm{Na}_{2} \mathrm{~S}$ was spiked into the sorption solution, about $2 \mathrm{mg} / \mathrm{L}$ sulfate $\left(\mathrm{SO}_{4}{ }^{2-}\right)$ was produced. According to the reaction:

$$
\mathrm{S}^{2-}+4 \mathrm{H}_{2} \mathrm{O}=\mathrm{SO}_{4}^{2-}+8 \mathrm{H}^{+}+8 \mathrm{e}^{-}
$$

this amount was equivalent to $0.67 \mathrm{mg} / \mathrm{L}$ sulfide ( $\mathrm{S}^{2-}$ ) being oxidized and suggested that sufficient sulfide remained in solution to influence redox conditions.

\section{Results and discussion}

\section{Utility of glove box to control redox conditions}

We first evaluated the approach of producing and maintaining different redox conditions in the radionuclideaquifer-groundwater system by controlling the air composition inside a glove box. This was accomplished by replacing the ambient air with $1 \% \mathrm{CO}_{2}$ in Ar. The change of oxygen content as a function of flow rate was controlled by adjusting incoming gas pressure; a steady-state level of 


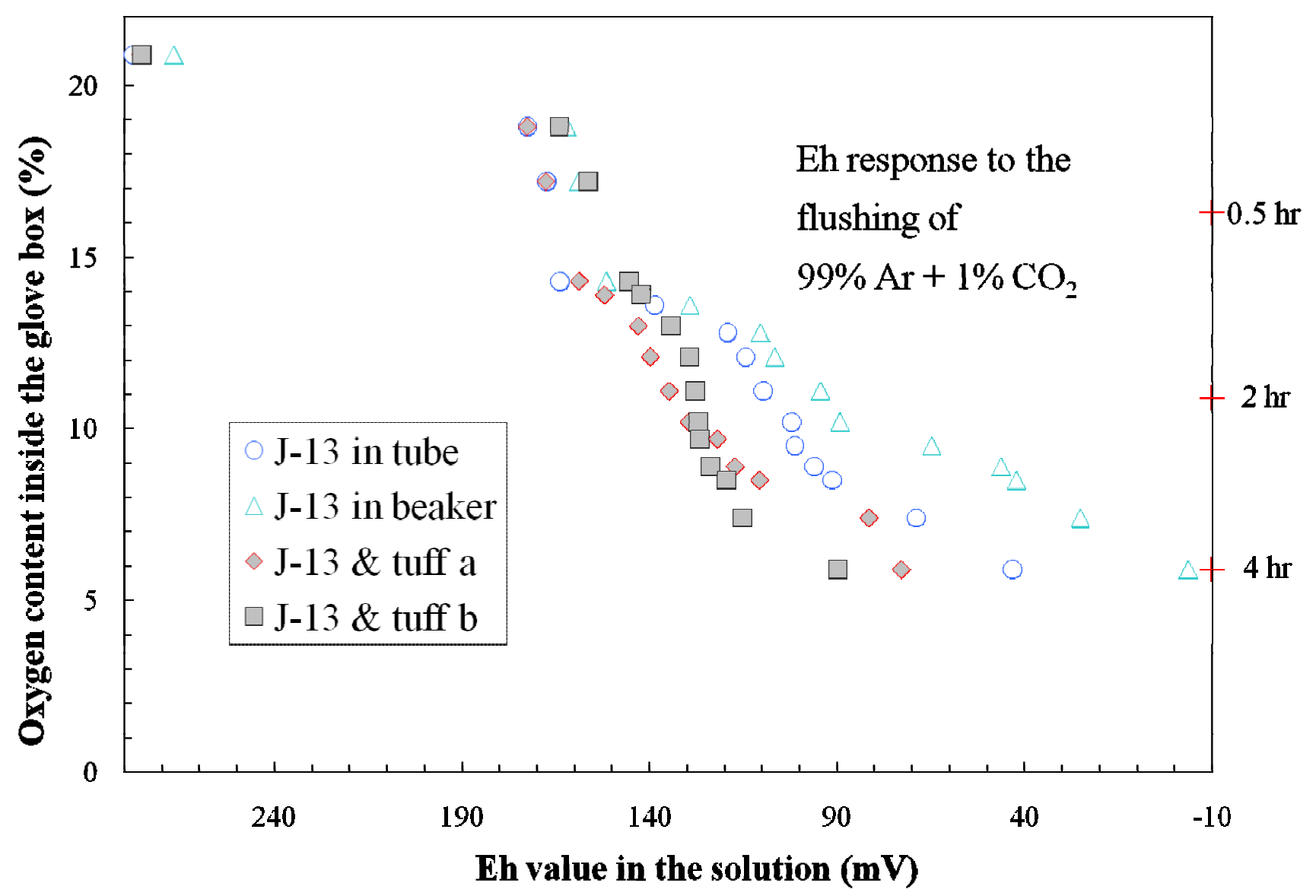

Figure 7

Change of solution Eh in response to the gas composition $\left(99 \% \mathrm{Ar}\right.$ and $\left.\mathrm{I} \% \mathrm{CO}_{2}\right)$ inside the glove box for J-I3 water and devitrified tuff (tuff $a$ and tuff $b$ are duplicate runs inside centrifuge tubes).

$\mathrm{O}_{2}$ inside the glove box was reached at about 2 hours under 10 psi and at 4 hours under 1 psi. Figures 6, 7 show the change of solution Eh in response to the flushing-out process of air inside a glove box. The Eh was periodically measured in background solutions, and all three background solutions exhibited a similar trend (i.e., similar behavior in redox buffering) (Figure 6). Figure 7 shows the effect of gas-water interface area and the redox buffering capacity of the crushed rock (devitrified tuff, in this case). As expected, J-13 water placed in a centrifuge tube $\left(1.8 \mathrm{~cm}^{2}\right.$ gas-water interface) responded, in terms of solution Eh, more slowly than that in a beaker with a gas-water interface area 9 times larger. The presence of solids (devitrified tuff, which provides buffering capacity) contributed to the maintenance of a higher solution Eh. Limited measurements of solution $\mathrm{pH}$ in $\mathrm{J}-13$ water showed a slight decrease from 7.91 at $20.9 \% \mathrm{O}_{2}$ to 7.67 at $10.3 \% \mathrm{O}_{2}$, while $\mathrm{pH}$ value for $\mathrm{J}-13$ and devitrified tuff at the same $\mathrm{O}_{2}$ levels decreased from 8.0 to 7.2 .
The test demonstrates the feasibility of achieving a range of more than $200 \mathrm{mV}$ in Eh under these experimental condition; further reduction can be obtained by applying a reductant $\left(\mathrm{FeCl}_{2}\right.$ or $\left.\mathrm{Na}_{2} \mathrm{~S}\right)$ in the sorption system. For Tests $\mathrm{D}$ and $\mathrm{E}$, a small amount of $\mathrm{FeCl}_{2}$ or $\mathrm{Na}_{2} \mathrm{~S}$ was added into the sorption solution, and $\mathrm{pH}$ was adjusted (with either $\mathrm{NH}_{4} \mathrm{OH}$ and/or $\mathrm{HNO}_{3}$ ) to be the same as the value before the spiking of the reductant.

\section{Sorption in radionuclide-aquifer-groundwater systems}

Table 4 and Figures 8, 9, 10, 11, 12, 13, 14 present the measured $K_{d} s$ (average \pm standard deviation for triplicates) of each radionuclide onto four different aquifers under six different redox conditions. The measured values were not necessarily the sorption coefficients at equilibration; the objective of these experiments was to study the relative effect of redox condition on radionuclide sorption under otherwise similar conditions.

By modifying the air composition and adding a reductant, we achieved an Eh range of nearly $400 \mathrm{mV}$ from Tests A to 
Table 4: The measured Kds (average \pm standard deviation for triplicates) of each radionuclide onto four different aquifers under five different redox conditions

\begin{tabular}{|c|c|c|c|c|c|c|c|c|c|}
\hline Test ID & $\begin{array}{c}\text { Test } \\
\text { Condition }\end{array}$ & $\mathrm{Sr}$ & Tc-99 & I & Cs & $\mathbf{R e}$ & Np-237 & $\mathbf{U}$ & Pu-242 \\
\hline A & atm & $50.4 \pm 1.65$ & $\begin{array}{c}(-0.099) \pm \\
0.064\end{array}$ & $0.74 \pm 0.02$ & $2078 \pm 304$ & $\begin{array}{c}(-0.20) \pm \\
0.07\end{array}$ & $52.3 \pm 4.40$ & $23.9 \pm 1.93$ & $437 \pm 147$ \\
\hline B & $1 \% \mathrm{O}_{2}$ & $50.6 \pm 0.54$ & $\begin{array}{c}(-0.052) \pm \\
0.035\end{array}$ & $0.35 \pm 0.09$ & $2275 \pm 415$ & $\begin{array}{c}(-0.03) \pm \\
0.05\end{array}$ & $77.4 \pm 2.48$ & $1022 \pm 114$ & $520 \pm 188$ \\
\hline C & $0.1 \% \mathrm{O}_{2}$ & $54.5 \pm 1.41$ & $\begin{array}{c}(-0.097) \pm \\
0.009\end{array}$ & $0.50 \pm 0.18$ & $2439 \pm 363$ & $\begin{array}{c}(-0.28) \pm \\
0.26\end{array}$ & $85.1 \pm 1.83$ & $782 \pm 7.06$ & $376 \pm 62.5$ \\
\hline $\mathrm{D}$ & $\begin{array}{l}\text { II ppm } \\
\mathrm{FeCl}_{2}\end{array}$ & $56.6 \pm 9.65$ & $\begin{array}{c}(-0.255) \pm \\
0.107\end{array}$ & $0.99 \pm 0.82$ & $2617 \pm 475$ & $0.014 \pm 0.44$ & $91.0 \pm 7.15$ & $1155 \pm 490$ & $518 \pm 436$ \\
\hline$E$ & $24 \mathrm{ppm} \mathrm{Na} \mathrm{N}_{2} \mathrm{~S}$ & $50.6 \pm 0.52$ & $\begin{array}{c}0.114 \pm \\
0.019\end{array}$ & $0.56 \pm 0.25$ & $3663 \pm 92.4$ & $0.44 \pm 0.05$ & $93.8 \pm 2.83$ & $182 \pm 70.4$ & $342 \pm 277$ \\
\hline
\end{tabular}

B. Distribution coefficient $\left(K_{d}, \mathrm{~mL} / \mathrm{g}\right)$ for radionuclides sorbed to devitrified tuff in synthetic J-13 water

\begin{tabular}{|c|c|c|c|c|c|c|c|c|c|}
\hline Test ID & $\begin{array}{c}\text { Test } \\
\text { Condition }\end{array}$ & Sr & Tc-99 & I & Cs & $\mathbf{R e}$ & Np-237 & $\mathbf{U}$ & Pu-242 \\
\hline A & atm & $26.0 \pm 2.60$ & $1.22 \pm 0.62$ & $0.43 \pm 0.83$ & $79.6 \pm 9.35$ & $0.20 \pm 0.48$ & $4.55 \pm 0.75$ & $6.64 \pm 0.35$ & $164 \pm 83.4$ \\
\hline B & $1 \% \mathrm{O}_{2}$ & $26.5 \pm 0.77$ & $2.10 \pm 1.00$ & $0.49 \pm 0.20$ & $89.6 \pm 6.65$ & $0.15 \pm 0.029$ & $20.9 \pm 6.34$ & $226 \pm 68.2$ & $168 \pm 149$ \\
\hline C & $0.1 \% \mathrm{O}_{2}$ & $30.2 \pm 0.38$ & $|2.5 \pm 4.4|$ & $0.64 \pm 0.12$ & $96.1 \pm 4.00$ & $\begin{array}{c}0.020 \pm \\
0.025\end{array}$ & $36.5 \pm 8.40$ & $89.4 \pm 6.93$ & $798 \pm 70.6$ \\
\hline $\mathrm{D}$ & $\begin{array}{l}\text { II ppm } \\
\mathrm{FeCl}_{2}\end{array}$ & $27.7 \pm 1.16$ & $19.1 \pm 11.4$ & $0.90 \pm 0.38$ & $99.5 \pm 6.40$ & $\begin{array}{c}0.263 \pm \\
0.245\end{array}$ & $69.6 \pm 30.7$ & $139 \pm 34.7$ & $\begin{array}{c}(-83.5) \pm \\
56.5\end{array}$ \\
\hline E & $24 \mathrm{ppm} \mathrm{Na} \mathrm{N}_{2} \mathrm{~S}$ & $25.4 \pm 0.92$ & $378 \pm 98.0$ & $0.61 \pm 0.13$ & $105 \pm 6.08$ & $0.56 \pm 0.29$ & $930 \pm 462$ & $268 \pm 42.6$ & $15.2 \pm 81.7$ \\
\hline
\end{tabular}

C. Distribution coefficients $\left(K_{d}, \mathrm{~mL} / \mathrm{g}\right)$ for radionuclides sorbed to carbonate rock in synthetic LCA water

\begin{tabular}{|c|c|c|c|c|c|c|c|c|c|}
\hline Test ID & $\begin{array}{c}\text { Test } \\
\text { Condition }\end{array}$ & Sr & Tc-99 & I & Cs & $\mathbf{R e}$ & Np-237 & $\mathbf{U}$ & Pu-242 \\
\hline A & $\mathrm{atm}$ & $0.96 \pm 0.32$ & $0.24 \pm 0.12$ & $0.72 \pm 0.03$ & $0.33 \pm 0.11$ & $\begin{array}{c}0.012 \pm \\
0.092\end{array}$ & $255 \pm 39.1$ & $2.22 \pm 0.63$ & $116 \pm 8.00$ \\
\hline B & $1 \% \mathrm{O}_{2}$ & $0.50 \pm 0.07$ & $0.12 \pm 0.16$ & $\begin{array}{c}(-0.11) \pm \\
0.01\end{array}$ & $0.19 \pm 0.12$ & $\begin{array}{c}(-0.11) \pm \\
0.05\end{array}$ & $228 \pm 16.1$ & $2.96 \pm 0.28$ & $162 \pm 12.6$ \\
\hline C & $0.1 \% \mathrm{O}_{2}$ & $0.98 \pm 0.12$ & $0.38 \pm 0.08$ & $0.39 \pm 0.29$ & $0.37 \pm 0.07$ & $0.23 \pm 0.07$ & $314 \pm 36.5$ & $3.31 \pm 0.14$ & $156 \pm 27.6$ \\
\hline$D$ & $\begin{array}{l}\text { II ppm } \\
\mathrm{FeCl}_{2}\end{array}$ & $1.37 \pm 0.39$ & $0.81 \pm 0.45$ & $0.52 \pm 0.35$ & $0.67 \pm 0.45$ & $0.32 \pm 0.35$ & $402 \pm 55.1$ & $\begin{array}{c}(-3.93) \pm \\
0.03\end{array}$ & $0.13 \pm 198$ \\
\hline$E$ & $24 \mathrm{ppm} \mathrm{Na} \mathrm{S}_{2} \mathrm{~S}$ & $0.89 \pm 0.39$ & $0.41 \pm 0.33$ & $0.38 \pm 0.35$ & $0.28 \pm 0.33$ & $\begin{array}{c}(-0.07) \pm \\
0.31\end{array}$ & $440 \pm 18.1$ & $\begin{array}{c}(-2.60) \pm \\
0.10\end{array}$ & $\begin{array}{c}(-0.14) \pm \\
0.50\end{array}$ \\
\hline
\end{tabular}

D. Distribution coefficients $\left(K_{d}, \mathrm{~mL} / \mathrm{g}\right)$ for radionuclides sorbed to to zeolitic tuff in TCU water

\begin{tabular}{|c|c|c|c|c|c|c|c|c|c|}
\hline Test ID & $\begin{array}{c}\text { Test } \\
\text { Condition }\end{array}$ & Sr & Tc-99 & $\mathbf{I}$ & Cs & $\mathbf{R e}$ & Np-237 & $\mathbf{U}$ & Pu-242 \\
\hline A & $\mathrm{atm}$ & $1080 \pm 350$ & $0.28 \pm 0.11$ & $\begin{array}{c}(-0.70) \pm \\
0.12\end{array}$ & $278 \pm 76.6$ & $\begin{array}{c}(-0.14) \pm \\
0.21\end{array}$ & $2.21 \pm 0.35$ & $1.79 \pm 0.30$ & $25.1 \pm 2.04$ \\
\hline B & $1 \% \mathrm{O}_{2}$ & $2637 \pm 932$ & $0.19 \pm 0.01$ & $0.79 \pm 0.39$ & $1164 \pm 306$ & $\begin{array}{c}0.049 \pm \\
0.039\end{array}$ & $2.07 \pm 0.10$ & $1.37 \pm 0.34$ & $65.3 \pm 17.0$ \\
\hline C & $0.1 \% \mathrm{O}_{2}$ & $1587 \pm 382$ & $\begin{array}{c}0.045 \pm \\
0.022\end{array}$ & $0.17 \pm 0.20$ & $1065 \pm 183$ & $\begin{array}{c}(-0.069) \pm \\
0.029\end{array}$ & $2.31 \pm 0.20$ & $4.12 \pm 0.09$ & $66.8 \pm 7.61$ \\
\hline$D$ & $\begin{array}{l}\text { II ppm } \\
\mathrm{FeCl}_{2}\end{array}$ & $\begin{array}{l}14264 \pm \\
12586\end{array}$ & $0.11 \pm 0.032$ & $0.07 \pm 0.71$ & $\begin{array}{c}16762 \pm \\
15951\end{array}$ & $\begin{array}{c}(-0.039) \pm \\
0.057\end{array}$ & $0.74 \pm 0.083$ & $7.25 \pm 0.56$ & $61.0 \pm 46.0$ \\
\hline$E$ & $24 \mathrm{ppm} \mathrm{Na}{ }_{2} \mathrm{~S}$ & $1019 \pm 612$ & $0.61 \pm 0.10$ & $0.70 \pm 0.14$ & $1790 \pm 2208$ & $0.64 \pm 0.88$ & $3.93 \pm 1.64$ & $8.21 \pm 2.53$ & $30.0 \pm 98.7$ \\
\hline
\end{tabular}

E measured at the end of 48 hours experimental duration (Table 5). As expected, for elements that were insensitive to redox conditions (i.e., $\mathrm{Sr}$ and $\mathrm{Cs}$ ), Kd values generally did not vary as a function of Eh for all four radionuclide- aquifer-groundwater systems (Table 4 and Figures 8, 9); observed small differences for carbonate and zeolitic tuff were probably related to the sample and analytical variability. Compared to the change in $\mathrm{Eh}$, values of $\mathrm{pH}$ among 


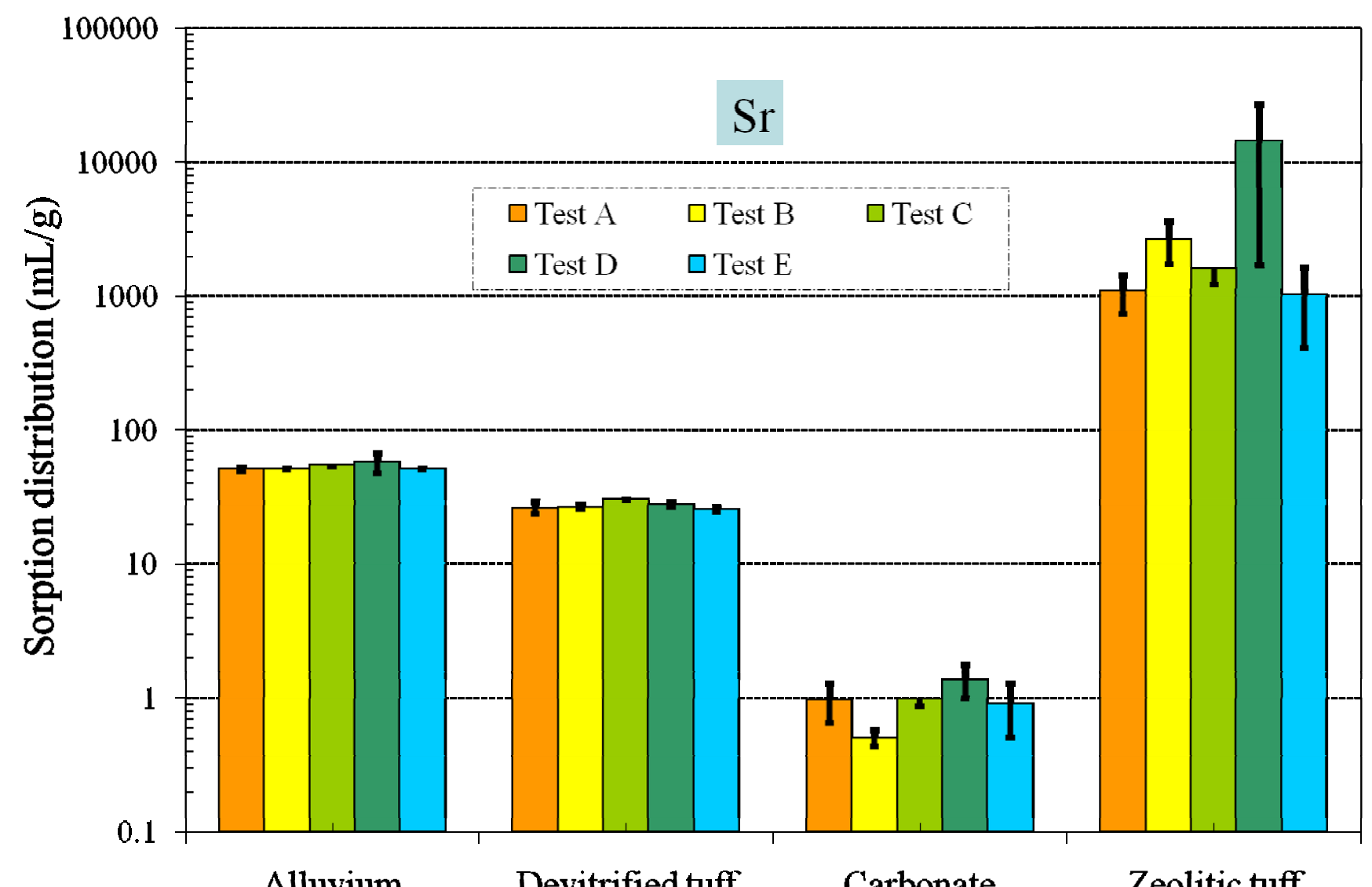

Figure 8

Change of $\mathrm{Sr} K_{d}$ values under five different redox conditions for different aquifer materials.

all treatments were relatively stable (Table 6). Under atmospheric (oxidizing) conditions (Test A), measured $\mathrm{Sr}$ sorption is moderate in alluvium and devitrified tuff, strong in zeolitic tuff, and weak in carbonate (Figure 8). Cs sorption patterns are similar to those of $\mathrm{Sr}$, being the strongest in alluvium, moderate in devitrified and zeolitic tuff, and very weak in carbonate (Figure 9).

For devitrified tuff, as solutions become more reducing from Tests A to E, the Tc $K_{d}$ increases (Figure 10); a slight $K_{d}$ increase in Test $\mathrm{E}$ ( $\mathrm{Na}_{2} \mathrm{~S}$ spiked samples) for alluvium and zeolitic tuff samples was also evident (Tables $4 \mathrm{a}$ and $4 d)$. Sorption of Re also seems to increase under more reducing conditions (Test $\mathrm{E}$ ) in devitrified tuff, alluvium, and zeolitic tuff, but the extent of increase was much smaller (Table 4). This was consistent with the greater stability of oxidized Re compared to Tc (discussed in-Reagents section). As reported by Lieser and Bauscher [9], if $\mathrm{TcO}_{4}{ }^{-}$is reduced by $\mathrm{Fe}(\mathrm{II})$ according to the reactions
$3 \mathrm{Fe}^{2+}+\mathrm{TcO}_{4}{ }^{-}+8 \mathrm{H}_{2} \mathrm{O}=3 \mathrm{Fe}(\mathrm{OH})_{3}+\mathrm{TcO}(\mathrm{OH})_{2}{ }^{\circ}+5 \mathrm{H}^{+}$,

hydrolytic adsorption of $\mathrm{TcO}(\mathrm{OH})_{2}{ }^{\circ}$ on iron (III) hydroxide or coprecipitation with $\mathrm{Fe}$ (III) by formation of hydroxo complexes containing $\mathrm{Fe}-\mathrm{O}-\mathrm{Tc}$ bonds can be expected. Once $\mathrm{TcO}_{4}{ }^{-}$has been reduced, precipitation or coprecipitation of $\mathrm{Tc}_{2} \mathrm{~S}_{7}$ may occur if $\mathrm{H}_{2} \mathrm{~S}$ or $\mathrm{S}^{2-}$ ions are present and the solubility product of the sparingly soluble $\mathrm{Tc}_{2} \mathrm{~S}_{7}$ has been exceeded. Non-zero Tc $K_{d}$ values were measured in all media except alluvium.

For devitrified tuff, the Tc $K_{d}$ value in Test E was 300 times higher than in Test A. It is not clear why the Eh decrease to a moderately reducing condition only has an effect on ${ }^{99} \mathrm{Tc}$ sorption/precipitation in devitrified tuff. We spectulate that a combination of factors contribute to the observed effect, and these factors include changes in the sorbate (redox speciation), the sorbent (surface property alteration), and the water chemistry (such as $\mathrm{pH}$ and $\mathrm{Fe}^{2+}$ $\mathrm{S}^{2-}$ concentrations). It is possible that the devitrified tuff has a trace amount of reducing mineral (e.g., pyrite) that 


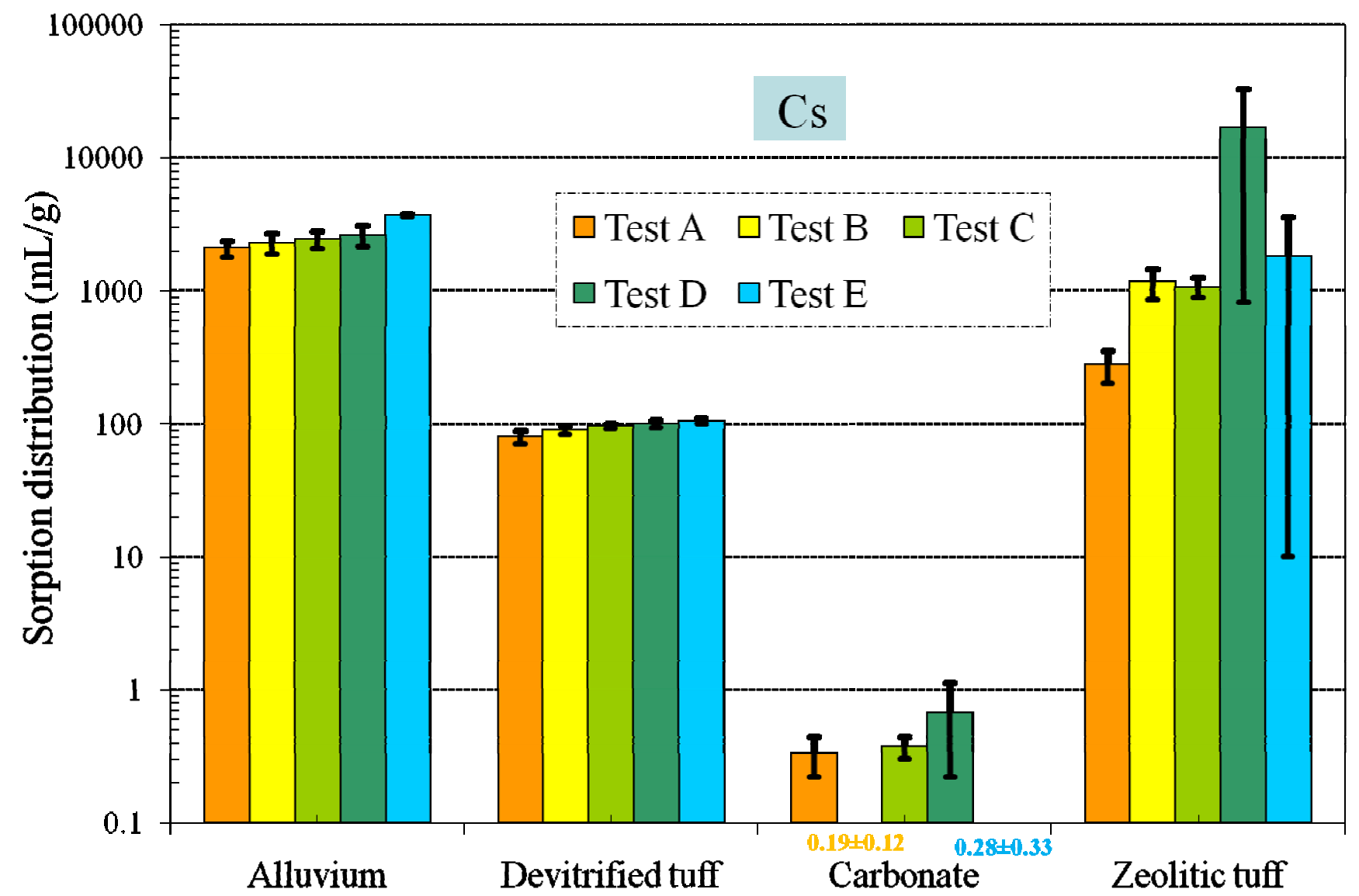

Figure 9

Change of $C s K_{d}$ values under five different redox conditions for different aquifer materials.

is not measurable by X-ray diffraction. The $\mathrm{Fe}_{2} \mathrm{O}_{3}$ content (wt \%) measured by X-ray fluorescence was reported to be $0.96 \pm 0.092$ for devitrified and 0.84 for zeolitic tuff, respectively [44]. The four aquifer materials had different aqueous iron concentrations after contact with background water, and also exhibited different response to added $\mathrm{Fe}^{2+}$ (Table 7). Both alluvium and devitrified tuff released some iron, but the alluvium seemed to be able to sorb added $\mathrm{Fe}^{2+}$ very effectively. Carbonate rock appeared to have effectively sorbed the added $\mathrm{Fe}^{2+}$ in Test D. Zeolitic tuff could release significant amounts of iron, and the amount released decreases from Tests A to $\mathrm{C}$ with an associated decrease in Eh value.

For the interaction of Tc with alluvium, there was essentially no sorption in Tests A to D (Table 4a). The measurable, though small, sorption of Tc in Test E for alluvium and zeolitic tuff suggested that Tc will be slightly retarded if the radionuclide encounters a reducing zone along its flowpath.
Some level of iodine (applied as iodide) sorption was observed in nearly all samples $\left(K_{d}=0-0.99 \mathrm{~mL} / \mathrm{g}\right)$. However, this sorption did not appear to be correlated with redox (Figure 11), therefore, some iodine retardation could help limit its transport in the subsurface at the NTS at any redox condition. Furthermore, the range of $K_{d}$ is substantially lower (and narrower) than the range proposed in Table 1, which is from the literature values confounded by iodine speciation (discussed in Background).

Under the atmospheric conditions, $\mathrm{Np}$ sorption is the strongest in carbonate rock, moderately strong in alluvium, and moderately weak in devitrified and zeolitic tuff, which is consistent with the literature [4]. Sorption of $\mathrm{Np}$ in devitrified tuff increased significantly with decreasing Eh; the Np $K_{d}$ value in Test E was 200 times higher than in Test A. It appears that a substantial quantity of $\mathrm{Np}(\mathrm{V})$ was reduced to $\mathrm{Np}(\mathrm{IV})$, leading to a strong retention similar to $\mathrm{Pu}(\mathrm{IV})$. This suggests that $\mathrm{Np}$ may be substantially retarded in mildly reducing groundwater conditions, con- 


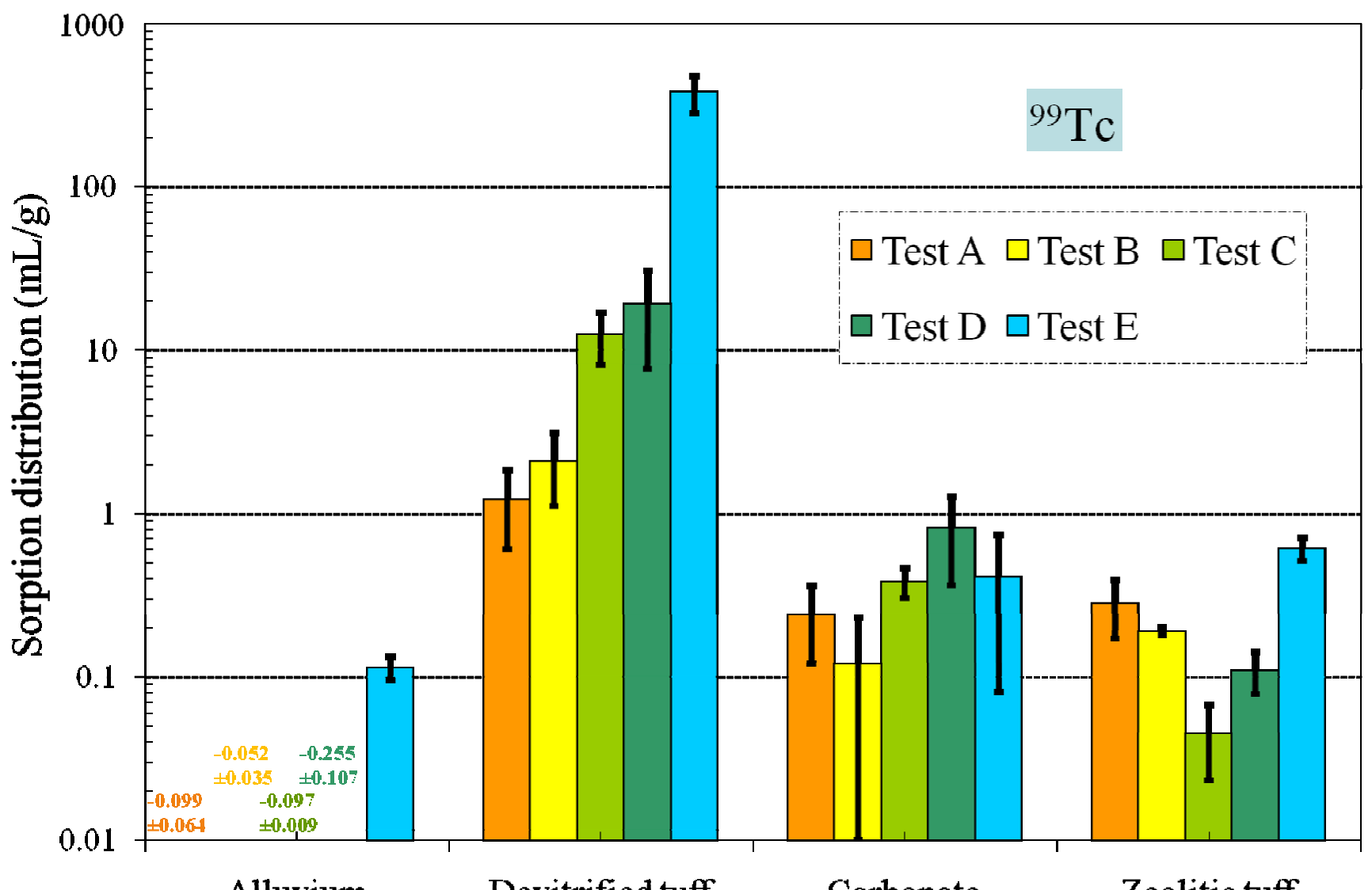

Figure 10

Change of ${ }^{99} \mathrm{Tc} K_{d}$ values under five different redox conditions for different aquifer materials.

trary to most Np transport predictions which assume that $\mathrm{Np}$ remains in the +5 oxidation state. Conversely, there was little change in Np sorption on alluvium and carbonate aquifer materials as a function of redox condition, which implies strong Np sorption to minerals in these two materials (e.g., calcite). Similar to what we obtained for
Test A under atmospheric condition, low $K_{d}$ values have been reported for Np in tuff [4], while nearly two orders of magnitude larger $K_{d}$ values were reported in carbonate [65]; Figure 12 shows a similar trend. Figure 15 presents the experimental Eh-pH ranges studied in this work overlaid on Np stability field plots for Np in LCA water. The

Table 5: Measured redox potential Eh $(\mathrm{mV})$, referenced to standard hydrogen electrode, in different treatments

\begin{tabular}{|c|c|c|c|c|c|c|c|c|c|c|c|}
\hline \multirow[t]{2}{*}{ Test ID } & \multicolumn{3}{|c|}{ Alluvium/J-I 3} & \multicolumn{2}{|c|}{ Devitrified tuff/J-I3 } & \multicolumn{3}{|c|}{ Zeolitic tuff/TCU } & \multicolumn{3}{|c|}{ Carbonate/LCA } \\
\hline & $\begin{array}{c}\mathrm{J}-13 \\
\text { Controla }\end{array}$ & Blank & Sorption & Blank & Sorption & Control & Blank & Sorption & Control & Blank & Sorption \\
\hline A & $362 \pm 13$ & $368 \pm 4.8$ & $312 \pm 9.9$ & $341 \pm 11$ & $338 \pm 10$ & $357 \pm 6.1$ & $340 \pm 5.7$ & $319 \pm 5.7$ & $345 \pm 4.5$ & $353 \pm 1.5$ & $335 \pm 4.2$ \\
\hline B & $\begin{array}{c}207 \pm \\
0.14\end{array}$ & $\begin{array}{c}205 \pm \\
0.64\end{array}$ & $206 \pm 2.0$ & $201 \pm 2.4$ & $203 \pm 2.0$ & $\begin{array}{l}186 \pm \\
0.215\end{array}$ & $\begin{array}{c}191 \pm \\
0.35\end{array}$ & $187 \pm 1.2$ & $195 \pm 2.8$ & $204 \pm 0.4$ & $195 \pm 0.4$ \\
\hline C & $\begin{array}{c}(-50) \pm \\
\text { I.0 }\end{array}$ & $\begin{array}{c}(-27) \pm \\
2.8\end{array}$ & $\begin{array}{c}(-3 I) \pm \\
I . I\end{array}$ & $\begin{array}{c}(-4 I) \pm \\
0.21\end{array}$ & $\begin{array}{c}(-22) \pm \\
0.31\end{array}$ & $\begin{array}{c}29.4 \pm \\
0.64\end{array}$ & $\begin{array}{c}(-8.3) \pm \\
0.21\end{array}$ & $\begin{array}{c}(-25) \pm \\
0.36\end{array}$ & $\begin{array}{c}(-35) \pm \\
0.64\end{array}$ & $\begin{array}{c}(-34) \pm \\
1.6\end{array}$ & $\begin{array}{c}(-22) \pm \\
\text { I.4 }\end{array}$ \\
\hline $\mathrm{D}$ & $\begin{array}{c}(-55) \pm \\
9.9\end{array}$ & $\begin{array}{c}(-83) \pm \\
0.07\end{array}$ & $\begin{array}{c}(-82) \pm \\
1.0\end{array}$ & $\begin{array}{c}(-82) \pm \\
0.78\end{array}$ & $\begin{array}{c}(-70) \pm \\
1.4\end{array}$ & $\begin{array}{c}(-98) \pm \\
1.3\end{array}$ & $\begin{array}{c}(-102) \pm \\
2.8\end{array}$ & $\begin{array}{c}(-95) \pm \\
0.60\end{array}$ & $\begin{array}{c}(-54) \pm \\
2.5\end{array}$ & $\begin{array}{c}(-90) \pm \\
0.14\end{array}$ & $\begin{array}{c}(-82) \pm \\
0.67\end{array}$ \\
\hline$E$ & $\begin{array}{c}(-50) \pm \\
1.0\end{array}$ & $\begin{array}{c}(-47) \pm \\
1.8\end{array}$ & $\begin{array}{c}(-63) \pm \\
6.5\end{array}$ & $\begin{array}{c}(-56) \pm \\
2.4\end{array}$ & $\begin{array}{c}(-59) \pm \\
2.7\end{array}$ & $\begin{array}{c}(-52) \pm \\
0.78\end{array}$ & $\begin{array}{c}(-69) \pm \\
0.21\end{array}$ & $\begin{array}{c}(-73) \pm \\
0.38\end{array}$ & $\begin{array}{c}(-52) \pm \\
0.14\end{array}$ & $\begin{array}{c}(-59) \pm \\
2.2\end{array}$ & $\begin{array}{c}(-68) \pm \\
0.85\end{array}$ \\
\hline
\end{tabular}

\footnotetext{
a The alluvium/J-13 control is also applicable for devitrified tuff/J-13 treatment.
} 


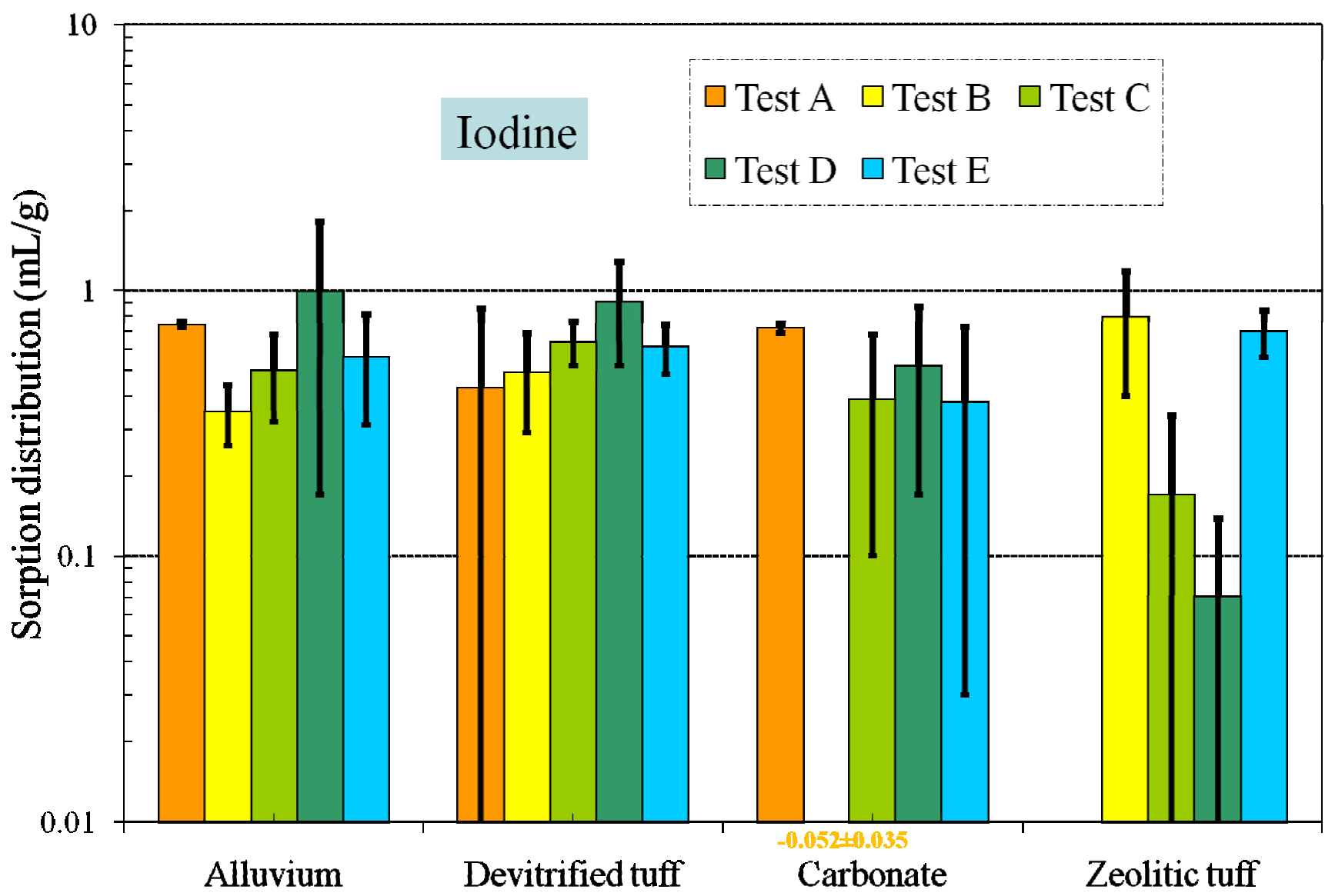

Figure I I

Change of iodine $K_{d}$ values under five different redox conditions for different aquifer materials.

likely $\mathrm{Np}$ species encountered in J-13 water would include $\mathrm{NpO}_{2} \mathrm{CO}_{3}{ }^{-}, \mathrm{NpO}_{2}{ }^{+}$, and $\mathrm{Np}(\mathrm{OH})_{4}$ (Figure 3). The reduced $\mathrm{Np}(\mathrm{OH})_{4}$ species is likely to sorb (or precipitate) much more strongly than the oxidized species, which is consistent with our observations of an increasing trend of $\mathrm{Np} K_{d}$ with decreasing Eh for devitrified tuff in J-13 water (Figure $3)$. For $\mathrm{Np}$ sorption in carbonate (Figure 15), $\mathrm{NpO}_{2} \mathrm{CO}_{3}$ and $\mathrm{NpO}_{2}{ }^{+}$species might have as strong an interaction with carbonate minerals as $\mathrm{Np}(\mathrm{OH})_{4}$ species, which would minimize the effect of Eh (Figure 12).

Table 6: Measured pH values in different treatments

\begin{tabular}{|c|c|c|c|c|c|c|c|c|c|c|c|}
\hline \multirow[t]{2}{*}{ Test ID } & \multicolumn{3}{|c|}{ Alluvium/J-13 } & \multicolumn{2}{|c|}{ Devitrified tuff/J-I3 } & \multicolumn{3}{|c|}{ Zeolitic tuff/TCU } & \multicolumn{3}{|c|}{ Carbonate/LCA } \\
\hline & $\begin{array}{c}\mathrm{J}-13 \\
\text { Control }\end{array}$ & Blank & Sorption & Blank & Sorption & Control & Blank & Sorption & Control & Blank & Sorption \\
\hline$A$ & $\begin{array}{c}7.63 \pm \\
0.27\end{array}$ & $\begin{array}{c}7.89 \pm \\
0.01\end{array}$ & $\begin{array}{c}7.84 \pm \\
0.04\end{array}$ & $\begin{array}{c}8.09 \pm \\
0.13\end{array}$ & $\begin{array}{c}7.89 \pm \\
0.09\end{array}$ & $\begin{array}{c}8.02 \pm \\
0.06\end{array}$ & $\begin{array}{c}7.91 \pm \\
0.08\end{array}$ & $\begin{array}{c}7.89 \pm \\
0.03\end{array}$ & $\begin{array}{c}8.01 \pm \\
0.08\end{array}$ & $\begin{array}{c}7.69 \pm \\
0.13\end{array}$ & $\begin{array}{c}7.84 \pm \\
0.09\end{array}$ \\
\hline B & $\begin{array}{c}8.50 \pm \\
0.34\end{array}$ & $\begin{array}{c}8.76 \pm \\
0.02\end{array}$ & $\begin{array}{c}8.48 \pm \\
0.03\end{array}$ & $\begin{array}{c}9.08 \pm \\
0.09\end{array}$ & $\begin{array}{c}8.32 \pm \\
0.03\end{array}$ & $\begin{array}{c}8.98 \pm \\
0.02\end{array}$ & $\begin{array}{c}9.27 \pm \\
0.04\end{array}$ & $\begin{array}{c}9.01 \pm \\
0.01\end{array}$ & $\begin{array}{c}8.05 \pm \\
0.04\end{array}$ & $\begin{array}{c}9.26 \pm \\
0.06\end{array}$ & $\begin{array}{c}8.59 \pm \\
0.02\end{array}$ \\
\hline $\mathrm{C}$ & $\begin{array}{c}8.72 \pm \\
0.15\end{array}$ & $\begin{array}{c}8.08 \pm \\
0.02\end{array}$ & $\begin{array}{c}8.70 \pm \\
0.06\end{array}$ & $\begin{array}{c}9.38 \pm \\
0.04\end{array}$ & $\begin{array}{c}8.66 \pm \\
0.06\end{array}$ & $\begin{array}{c}8.95 \pm \\
0.20\end{array}$ & $\begin{array}{c}8.30 \pm \\
0.03\end{array}$ & $\begin{array}{c}9.04 \pm \\
0.04\end{array}$ & $\begin{array}{c}9.64 \pm \\
0.03\end{array}$ & $\begin{array}{c}9.35 \pm \\
0.14\end{array}$ & $\begin{array}{c}8.89 \pm \\
0.23\end{array}$ \\
\hline $\mathrm{D}$ & $\begin{array}{c}7.79 \pm \\
0.04\end{array}$ & $\begin{array}{c}8.97 \pm \\
0.09\end{array}$ & $\begin{array}{c}8.89 \pm \\
0.03\end{array}$ & $\begin{array}{c}8.57 \pm \\
0.08\end{array}$ & $\begin{array}{c}8.51 \pm \\
0.06\end{array}$ & $\begin{array}{c}9.54 \pm \\
0.01\end{array}$ & $\begin{array}{c}9.66 \pm \\
0.03\end{array}$ & $\begin{array}{c}9.63 \pm \\
0.08\end{array}$ & $\begin{array}{c}9.36 \pm \\
0.10\end{array}$ & $\begin{array}{c}9.50 \pm \\
0.24\end{array}$ & $\begin{array}{c}9.15 \pm \\
0.03\end{array}$ \\
\hline$E$ & $\begin{array}{c}8.40 \pm \\
0.05\end{array}$ & $\begin{array}{c}9.11 \pm \\
0.17\end{array}$ & $\begin{array}{c}9.01 \pm \\
0.02\end{array}$ & $\begin{array}{c}9.50 \pm \\
0.05\end{array}$ & $\begin{array}{c}8.75 \pm \\
0.05\end{array}$ & $\begin{array}{c}9.68 \pm \\
0.01\end{array}$ & $\begin{array}{c}9.85 \pm \\
0.01\end{array}$ & $\begin{array}{c}9.72 \pm \\
0.01\end{array}$ & $\begin{array}{c}8.54 \pm \\
0.11\end{array}$ & $\begin{array}{c}9.51 \pm \\
0.14\end{array}$ & $\begin{array}{c}9.28 \pm \\
0.04\end{array}$ \\
\hline
\end{tabular}




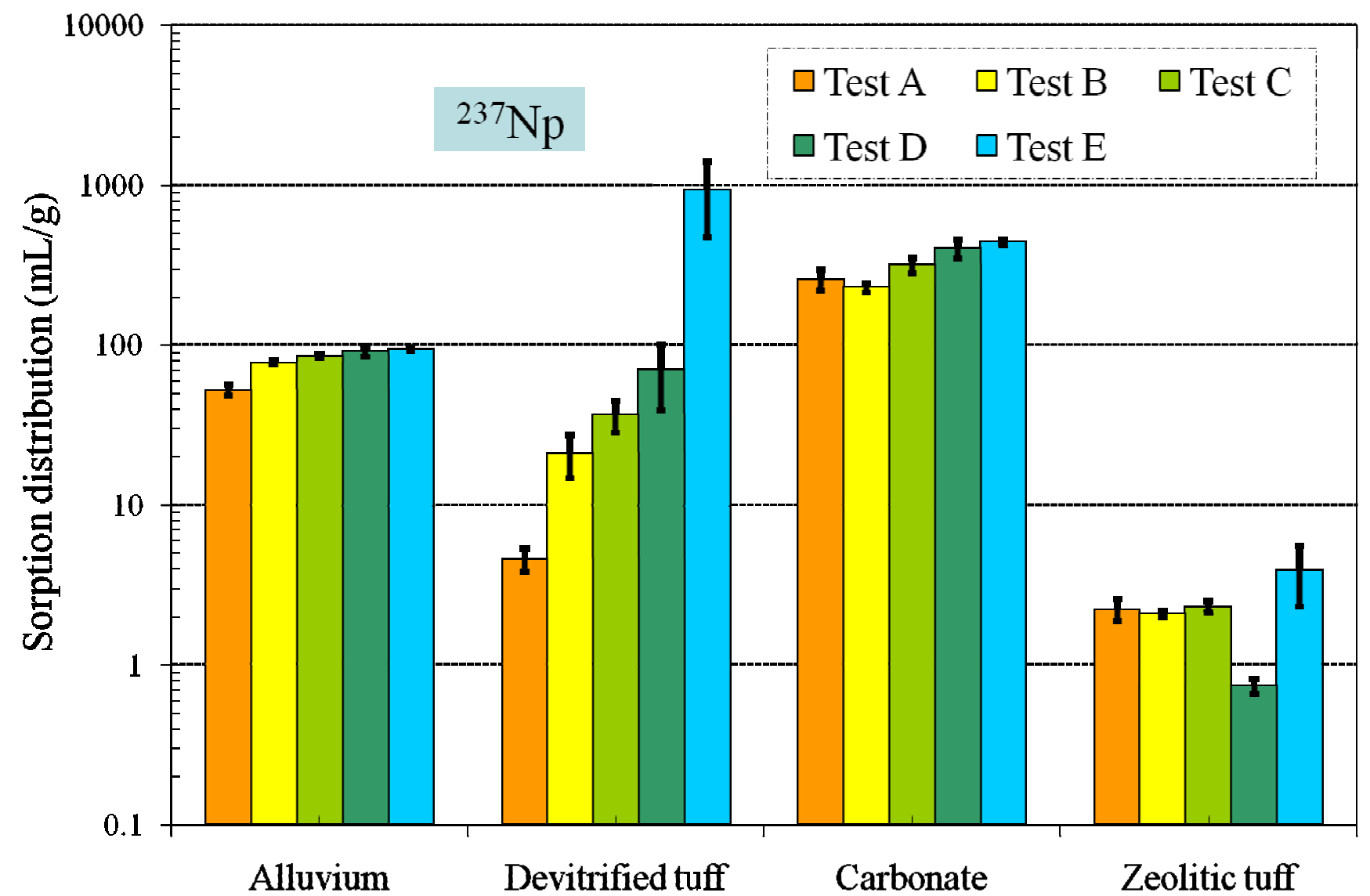

Figure 12

Change of ${ }^{237} \mathrm{~Np} K_{d}$ values under five different redox conditions for different aquifer materials.

Overall, uranium $K_{d}$ values in Tests B to E for alluvium, devitrified tuff, and zeolitic tuff (except for Test B) were larger than in Test A, which was conducted under atmos- pheric conditions (Figure 13 and Table 4C). Measured uranium $\mathrm{K}_{d}$ s to carbonate in Tests $\mathrm{D}$ and $\mathrm{E}$ were negative (-3.9 and $-2.6 \mathrm{~mL} / \mathrm{g}$, respectively). Low initial U concen-

Table 7: Measured iron concentrations $(\mu \mathrm{g} / \mathrm{L})$ in $0.2-\mu \mathrm{m}$ filtrate in different treatments

\begin{tabular}{|c|c|c|c|c|c|c|c|c|c|c|c|}
\hline \multirow[t]{2}{*}{ Test ID } & \multicolumn{3}{|c|}{ Alluvium/J-13 } & \multicolumn{2}{|c|}{ Devitrified tuff/J-13 } & \multicolumn{3}{|c|}{ Zeolitic tuff/TCU } & \multicolumn{3}{|c|}{ Carbonate/LCA } \\
\hline & $\begin{array}{c}\mathrm{J}-13 \\
\text { Control }\end{array}$ & Blank & Sorption & Blank & Sorption & Control & Blank & Sorption & Control & Blank & Sorption \\
\hline A & $\mathrm{ND}^{\mathrm{a}}$ & $\begin{array}{c}1038 \pm \\
1520\end{array}$ & ND & $\begin{array}{c}|4| 4 \pm \\
22 \mid\end{array}$ & $\begin{array}{c}557 \pm \\
435\end{array}$ & ND & $\begin{array}{c}27,752 \pm \\
5,894\end{array}$ & $\begin{array}{c}26,328 \pm \\
4,882\end{array}$ & ND & ND & $106 \pm 36$ \\
\hline B & ND & $703 \pm 957$ & $15.0 \pm 5.7$ & $98.5 \pm 7.2$ & $\begin{array}{c}260 \pm \\
347\end{array}$ & ND & $\begin{array}{c}5,545 \pm \\
4,139\end{array}$ & $\begin{array}{c}4,465 \pm \\
3,050\end{array}$ & ND & $\begin{array}{c}6.94 \pm \\
5.00\end{array}$ & $\begin{array}{c}12.4 \pm \\
21.6\end{array}$ \\
\hline C & $160 \pm 118$ & $\begin{array}{c}219 \pm \\
32.7\end{array}$ & $\begin{array}{c}32.1 \pm \\
20.4\end{array}$ & $639 \pm 634$ & $\begin{array}{c}108 \pm \\
46.3\end{array}$ & ND & 123 & $\begin{array}{c}3,539 \pm \\
3,136\end{array}$ & ND & $\begin{array}{c}16.0 \pm \\
10.2\end{array}$ & $\begin{array}{c}6.47 \pm \\
11.6\end{array}$ \\
\hline $\mathrm{D}^{\mathrm{b}}$ & $\begin{array}{l}891 \pm \\
1193\end{array}$ & $\begin{array}{c}90.0 \pm \\
60.4\end{array}$ & $\begin{array}{c}5.65 \pm \\
4.65\end{array}$ & $230 \pm 86$ & $\begin{array}{c}279 \pm \\
149\end{array}$ & $\begin{array}{l}958 \pm \\
1,37 \mid\end{array}$ & $\begin{array}{c}2,185 \pm \\
1,624\end{array}$ & $\begin{array}{c}1,307 \pm \\
1,330\end{array}$ & $\begin{array}{c}187 \pm \\
224\end{array}$ & ND & $\begin{array}{c}171 \pm \\
254\end{array}$ \\
\hline E & ND & $865 \pm 489$ & $\begin{array}{c}9.84 \pm \\
13.7\end{array}$ & $\begin{array}{c}199 \pm \\
74.0\end{array}$ & $\begin{array}{c}82.5 \pm \\
20.8\end{array}$ & ND & $\begin{array}{c}4,734 \pm \\
491\end{array}$ & $\begin{array}{c}5,475 \pm \\
4,227\end{array}$ & $\begin{array}{c}27.3 \pm \\
17.7\end{array}$ & ND & $\begin{array}{c}33.5 \pm \\
5.56\end{array}$ \\
\hline
\end{tabular}

a ND: not detected; below the detection limit of about $5 \mu \mathrm{g} / \mathrm{L}$.

b" I ppm" $\mathrm{FeCl}_{2}$ was added into both background and tracer sorption solutions used in Test $\mathrm{D}$. Measured Fe ${ }^{2+}$ concentrations in the control samples are in the range of 0.2 to I Ppm, which is consistent with the excepted dissolved Fe ${ }^{2+}$ concentrations from Geochemist's Workbench; the $\mathrm{Fe}^{2+}$ in solution is controlled by the solubility of $\mathrm{FeCO}_{3}$ and/or $\mathrm{Fe}(\mathrm{OH})_{2}$. 


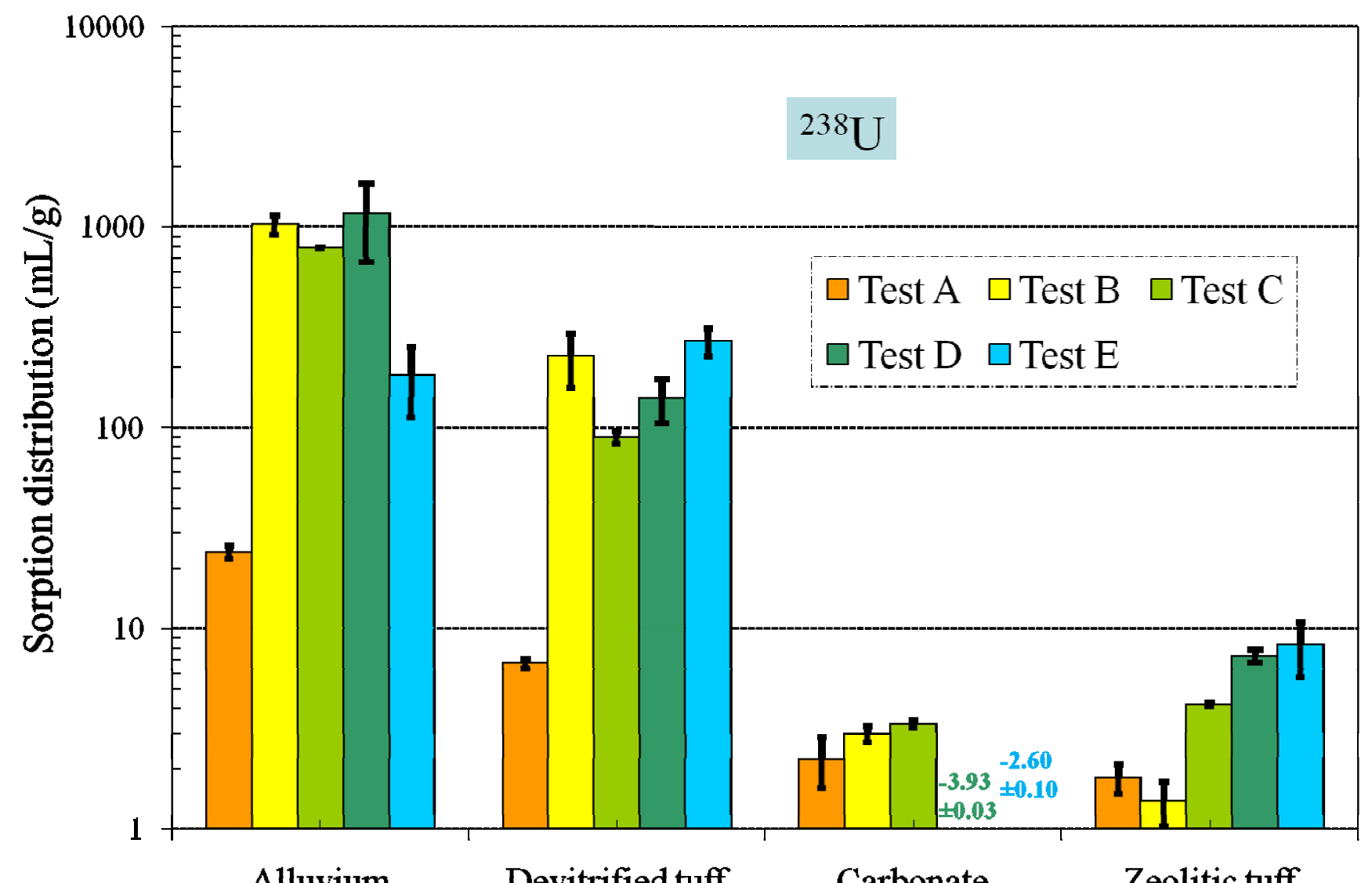

Figure 13

Change of $U K_{d}$ values under five different redox conditions for different aquifer materials.

trations in spiked blanks (Table $2 \mathrm{~b}$ ) suggest that precipitation of uranium or losses to container walls had an effect on these samples. The low initial iodine and Pu concentrations in spiked blanks for Tests D and E were also observed (Table $2 \mathrm{~b}$ ). The addition of a reductant consistently affected the initial solution concentrations of U, I, and Pu more than other elements (Table 2); reducing conditions exacerbate issues regarding precipitation or sorption to container walls for these elements.

Using 1 mM sulfide, Beyenal et al. [66] reported the reduction and total removal of about 53,000 $\mu \mathrm{g} / \mathrm{L}(140 \mu \mathrm{M})$ $\mathrm{U}(\mathrm{VI})$ from solution. The $\mathrm{U}(\mathrm{VI})$ was found to be precipitated as U(IV)-uraninite. We used $\sim 0.33 \mathrm{mM}$ sulfide (24 ppm $\mathrm{Na}_{2} \mathrm{~S}$ ) and an initial U(VI) concentration of $\sim 1,000$ $\mu \mathrm{g} / \mathrm{L}$. The highest $K_{d}$ measured under these conditions was $268 \mathrm{~mL} / \mathrm{g}$ (98\% removal, devitrified tuff); the lowest was $8 \mathrm{~mL} / \mathrm{g}$ (60\% removal, zeolitic tuff). Hua et al. [67] suggested the reaction stoichiometry of $\mathrm{U}(\mathrm{VI})$ reduction by hydrogen sulfide could be best described by

$$
\mathrm{HS}^{-}+\mathrm{UO}_{2}^{2+}=\mathrm{UO}_{2}+\mathrm{S}^{0}+\mathrm{H}^{+}
$$

The kinetics of $\mathrm{U}(\mathrm{VI})$ reduction was found to be largely controlled by the total carbonate concentration and $\mathrm{pH}$. They further concluded that uranium-hydroxyl species, not the dominant U-carbonate species, were the ones being reduced by sulfide. Our experiments suggest that a combination of water chemistry and rock mineralogy will affect the efficiency of sulfide-promoted U(VI) reduction.

Compared to other tests, sorption of $\mathrm{Pu}$ is more variable for Tests D and E and most likely the result of Pu loss to container walls, as described earlier. Overall, Pu sorption seems not to be significantly affected by the decreasing redox conditions achieved in this study (Figure 14). This is especially evident for alluvium and zeolitic tuff samples. The predominant $\mathrm{Pu}$ species at all redox conditions was the sparingly-soluble and strongly sorbing $\mathrm{Pu}(\mathrm{OH})_{4}$ (Figure 4). At low pH $(<7)$ and highly reducing conditions, Pu may exist as $\mathrm{Pu}(\mathrm{III})$. However, this species is also a very strong sorber. Overall, Pu sorption onto NTS aqui- 


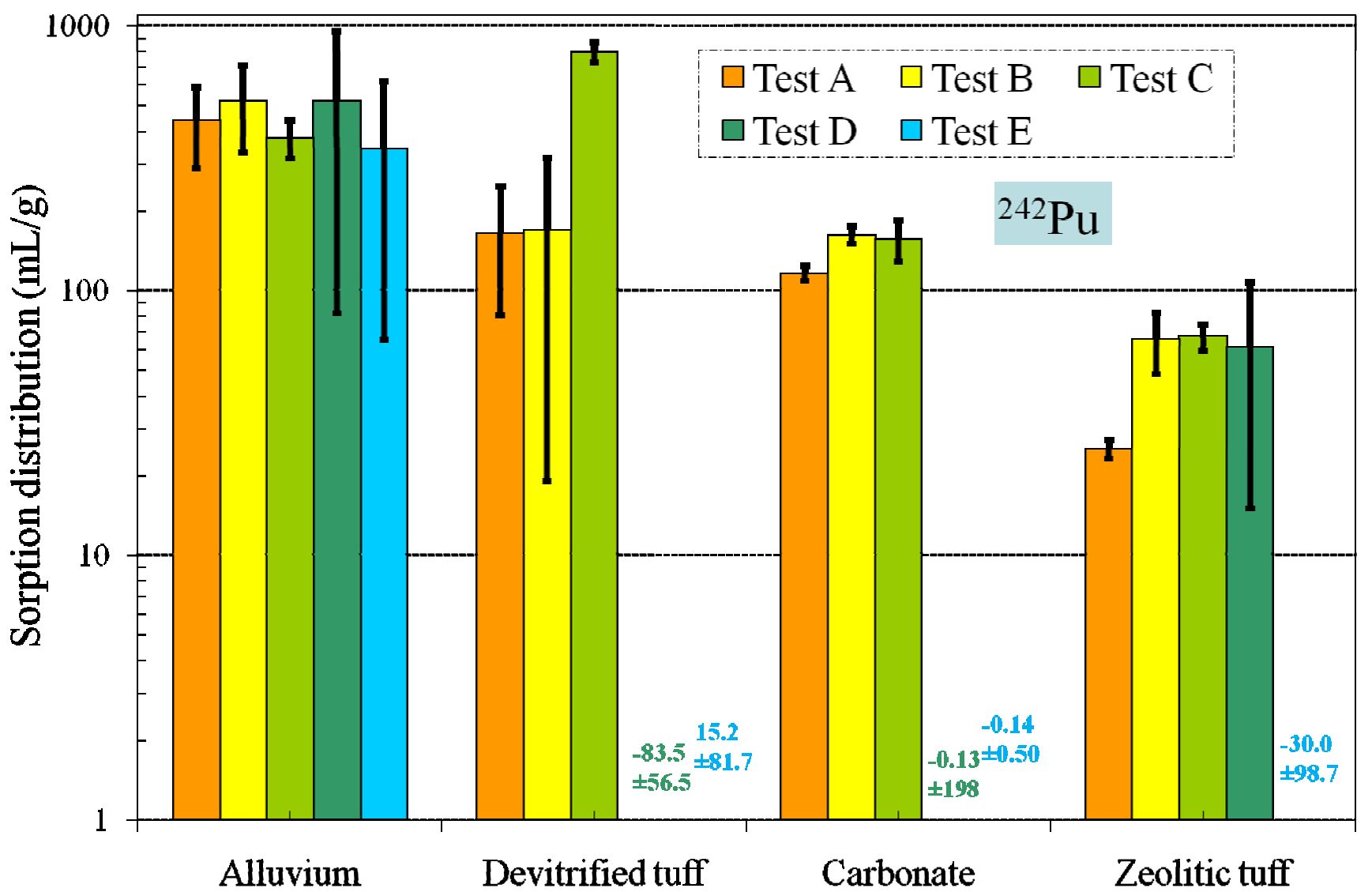

Figure 14

Change of ${ }^{242} \mathrm{Pu} K_{d}$ values under five different redox conditions for different aquifer materials.

fers is much less affected by redox than other redox-sensitive radionuclides.

\section{Conclusion}

This work describes the effect of reducing groundwater on the retardation of redox-sensitive radionuclides in the NTS. Based on our review of literature and experimental results, we have the following conclusions:

- Laboratory batch-sorption experiments showed markedly greater retardation for ${ }^{99} \mathrm{Tc}$ and ${ }^{237} \mathrm{~Np}$ in devitrified tuff under reducing conditions. Retardation of radionuclides as a function of redox condition is particularly important for ${ }^{99} \mathrm{Tc}$, which would be highly mobile under oxidizing conditions. The ${ }^{99} \mathrm{Tc} K_{d}$ in devitrified tuff correlated with redox, increasing from 1.22 to $378 \mathrm{~mL} / \mathrm{g}$ from oxidizing to mildly reducing. Under oxidizing conditions, measured ${ }^{99} \mathrm{Tc} K_{d}$ values were $0.12-0.81 \mathrm{~mL} / \mathrm{g}$ in carbonate rock, $0.045-0.61 \mathrm{~mL} / \mathrm{g}$ in zeolitic tuff, and $\sim 0 \mathrm{~mL} / \mathrm{g}$ in alluvium.
- Under the experimental conditions, values for $K_{d}$ of iodine are generally not correlated with redox; $K_{d} s$ were $0.33-0.99,0.43-0.90,0-0.72$ and $0-0.79 \mathrm{~mL} / \mathrm{g}$ for alluvium, devitrified tuff, carbonate, and zeolitic tuff. Importantly, a non-zero $K_{d}$ was observed in all samples, suggesting that ${ }^{129} \mathrm{I}$ transport will be retarded. Including the measurable $K_{d}$ for $^{129}$ I iodine would result in less conservative and more realistic radionuclide transport predictions.

- The Np $K_{d}$ strongly correlated with redox condition in devitrified tuff, with an increase from 4.6 to $930 \mathrm{~mL} / \mathrm{g}$ as experimental conditions became more reducing. The probable reduction of $\mathrm{Np}(\mathrm{V})$ to $\mathrm{Np}(\mathrm{IV})$, and comparable $K_{d}$ to $\mathrm{Pu}(\mathrm{IV})$, under mildly reducing conditions has not been widely reported in the literature.

- The overall trend showed that the sorption of U for alluvium, devitrified tuff, and zeolitic tuff under atmospheric conditions was smaller than the glove-box tests. 


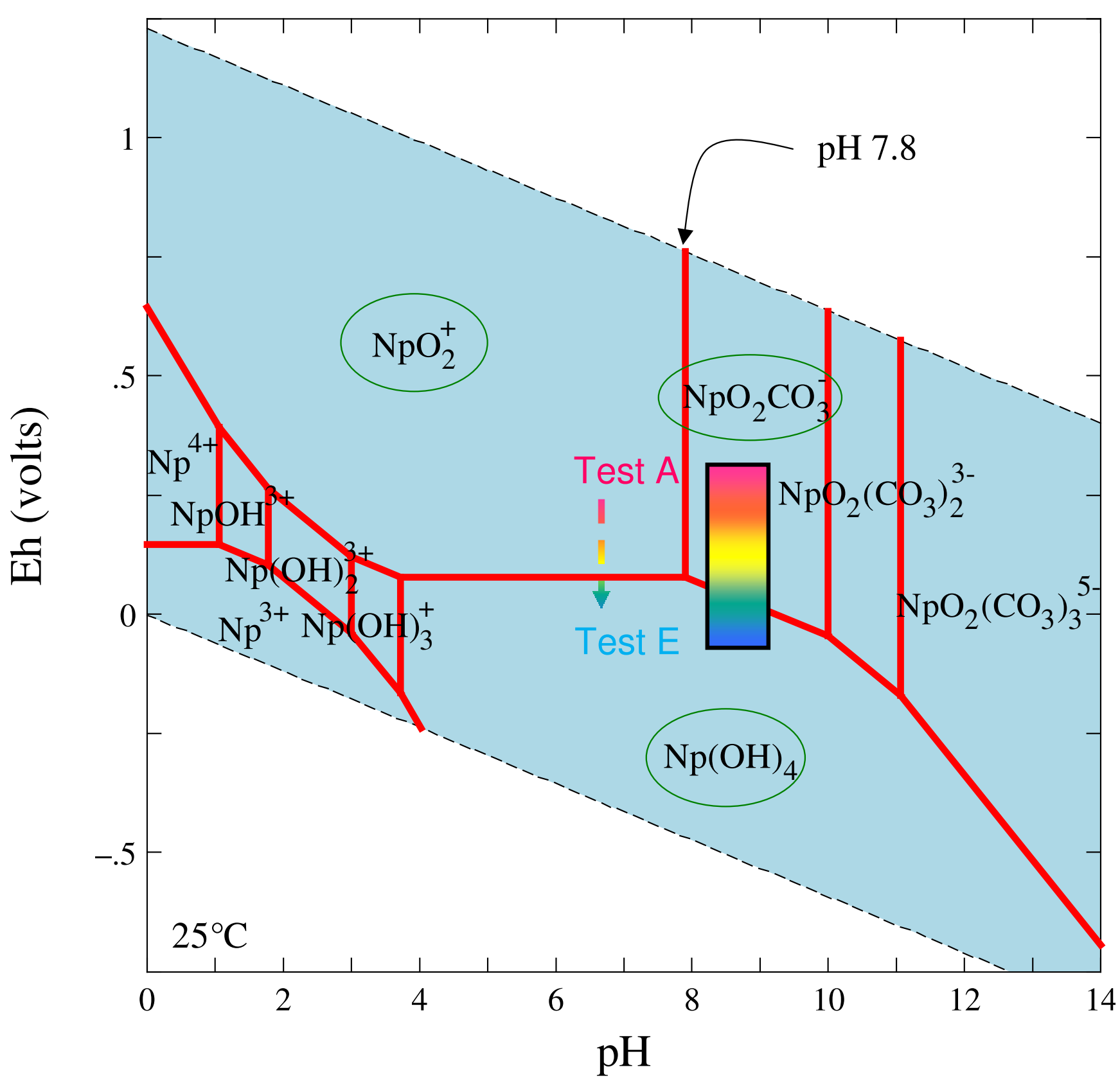

Figure 15

Stability fields of Np species in Eh-pH diagram for LCA waters.

- Sorption of Pu was not affected by the decreasing redox conditions achieved in this study, as the predominant Pu species in all conditions was expected to be sparingly-soluble and strongly sorptive $\mathrm{Pu}(\mathrm{OH})_{4}$.

The probable presence of reducing groundwater zones in the subsurface could potentially contribute to the retardation of some redox-sensitive radionuclides. Understand- ing of redox conditions on the transport of redox-sensitive radionuclides garnered from this study at the NTS is very important in assessing potential contaminant mobility and developing remediation strategy in other contaminated sites.

\section{Competing interests}

The authors declare that they have no competing interests. 


\section{Authors' contributions}

QHH designed the tests, performed the experiments and speciation modeling, interpreted data, and drafted the manuscript, MZ was involved in data interpretation and revising the manuscript, and TPR assisted with data interpretation and revising the manuscript. All authors have approved the significance of the work, interpretation of results, and contents of the final manuscript.

\section{Acknowledgements}

Funding for this investigation was provided by the Environment Restoration Division's Underground Test Area Project at the US Department of Energy, National Nuclear Security Administration, Nevada Site Office. This work was performed under the auspices of the U.S. Department of Energy by Lawrence Livermore National Laboratory (LLNL) under Contract DEAC52-07NA27344. Helpful comments from the handling editor and three anonymous reviewers are also very much appreciated.

\section{References}

I. Ahearne JF: Radioactive waste: The size of the problem. Phys Today 1997, 50(6):24-29.

2. Ewing RC: Environmental impact of the nuclear fuel cycle. In Energy, Waste and the Environment: A Geochemical Perspective Edited by: Gieré R, Stille P. Geological Society Special Publication 236, The Geological Society, London; 2004:7-23.

3. Smith DK, Finnegan DL, Bowen SM: An inventory of long-lived radionuclides residual from underground nuclear testing at the Nevada test site, 195I-1992. J Environ Radioact 2003, 67:35-51.

4. Stoller-Navarro Joint Venture (SNJV): Phase II Contaminant Transport Parameters for the Groundwater Flow and Contaminant Transport Model of Corrective Action Unit 98: Frenchman Flat, Nye County, Nevada. Las Vegas, NV: S-N/99205-043 2005 [http://www.osti.gov/energycitations/ product.biblio.jsp?osti id $=875996$.

5. Roden EE, Scheibe TD: Conceptual and numerical model of uranium(VI) reductive immobilization in fractured subsurface sediments. Chemosphere 2005, 59(5):617-628.

6. Wang $Y$, Salvage K: Immobilization of uranium in the presence of $\mathrm{FeO}(\mathrm{s})$ : Model development and simulation of contrasting experimental conditions. Appl Geochem 2005, 20(7): I 268-I 283.

7. Triay IR, Meijer A, Conca JL, Kung KS, Rundberg RS, Strietelmeier BA, Tait CD: Summary and synthesis report on radionuclide retardation for the Yucca Mountain Site Characterization Project. In Los Alamos National Laboratory Los Alamos, NM: Milestone 3784M; 1997.

8. Zavarin M, Carle SF, Maxwell RM: Upscaling radionuclide retardation - Linking the surface complexation and ion exchange mechanistic approach to a linear $K_{d}$ approach. 2004:165 [http:/ /www.osti.gov/energycitations/product.biblio.jsp?osti id=| 5014299 ]. Lawrence Livermore National Laboratory, Livermore, CA: UCRLTR-2047I3

9. Lieser $\mathrm{KH}$, Bauscher $\mathrm{CH}$ : Technetium in the hydrosphere and in the geosphere. I. Chemistry of technetium and iron in natural waters and influence of the redox potential on the sorption of technetium. Radiochim Acta 1987, 42:205-2I3.

10. Eriksen TE, Ndalamba $P$, Bruno J, Caceci $M$ : The solubility of $\mathrm{TCO}_{2} \cdot \mathrm{nH}_{2} \mathrm{O}$ in neutral to alkaline solutions under constant pCO $_{2}$. Radiochim Acta 1992, 58/59:67-70.

II. Fredrickson JK, Zachara JM, Kennedy DW, Kukkadupa RK, McKinley JP, Heald SM, Liu C, Plymale AE: Reduction of $\mathrm{TCO}_{4}^{-}$by sedimentassociated biogenic Fe(II). Geochim Cosmochim Acta 2004, 68:317I-3I87.

12. Bondietti EA, Francis CW: Geologic migration potentials of Tc99 and Np-237. Science 1979, 203:1337-1340.

13. BSC (Bechtel SAIC Company), Site-Scale Saturated Zone Transport: Appendix F: Redox Measurements in Saturated Zone Waters. NDL-NBS-HS-0000 I 0, Rev. 02. 2004:297-3/2 [http:// www.osti.gov/energycitations/purl.cover.jsp?purl=/886569-IBv4Ne/]. Las Vegas, Nevada: Bechtel SAIC Company
14. Hu QH, Rose TP, Zavarin M, Smith DK, Moran JE, Zhao PH: Assessing field-scale migration of radionuclides at the Nevada Test Site: "Mobile" species. J Environm Radioact 2008, 99:1617-1630.

15. Cui $D$, Eriksen TE: Reduction of pertechnetate in solution by heterogeneous electron transfer from $\mathrm{Fe}$ (II)-containing geological material. Environ Sci Technol 1996, 30:2263-2269.

16. Cui D, Eriksen TE: Reactive transport of Sr, Cs and Tc through a column packed with fracture-filling material. Radiochim Acta 1998, 82:287-292.

17. Cui $D$, Eriksen TE: Reduction of pertechnetate by ferrous iron in solution: Influence of sorbed and precipitated Fe(II). Environ Sci Technol 1996, 30:2259-2262.

18. Zachara JM, Heald SM, Jeon BH, Kukkadapu RK, Liu CX, McKinley JP, Dohnalkova AC, Moore DA: Reduction of pertechnetate [Tc(VII)] by aqueous $\mathrm{Fe}(\mathrm{II})$ and the nature of solid phase redox products. Geochim Cosmochim Acta 2007, 7 I:2137-2 157.

19. Peretyazhko T, Zachara JM, Heald SM, Jeon BH, Kukkadapu RK, Liu CX, Moore D, Resch CT: Heterogeneous reduction of Tc(VII) by $\mathrm{Fe}(\mathrm{II})$ at the solid-water interface. Geochim Cosmochim Acta 2008, 72(6): $1521-1539$.

20. Arnold BW, Meijer A, Kalinina E, Robinson BA, Kelkar S, Jove-Colon $C$, Kuzio SP, James S, Zhu M: Impacts of reducing conditions in the saturated zone at Yucca Mountain. Proceedings of the IIth International High-Level Radioactive Waste Management Conference (IHLRWM) 2006:345-352.

21. Couture RA, Seitz MG: Sorption of anions of iodine by iron oxides and kaolinite. Nucl Chem Waste Manag 1983, 4:30I-306.

22. Sheppard M, Thibault DH: Chemical behavior of iodine in organic and mineral soils. Appl Geochem 1992, 7:265-272.

23. Hu QH, Zhao P, Moran JE, Seaman JC: Sorption and transport of iodine species in sediments from the Savannah River and Hanford Sites. J Contam Hydrol 2005, 78(3): | 85-205.

24. Kim Jl: Chemical behaviour of transuranic elements in natural aquatic systems. In Handbook on the Physics and Chemistry of the Actinides Volume 4. Edited by: Freeman AJ, Keller C. Elsevier, Amsterdam; 1986:413-455.

25. Dozol M, Hagemann R: Radionuclide migration in groundwaters: Review of the behaviour of actinides. Pure Appl Chem 1993, 65:1081-1102.

26. Silva RJ, Nitsche H: Actinide environmental chemistry. Radiochim Acta 1995, 70/7 I:377-396.

27. Kersting AB, Reimus PW: Colloid-Facilitated Transport of LowSolubility Radionuclides: A Field, Experimental, and Modeling Investigation. 2003:285 [http://www.osti.gov/energycitations/ product.biblio.jsp?osti id= 15006520$]$. Lawrence Livermore National Laboratory Report, Livermore, CA: UCRL-ID- 49688 (checked on 7/ 28/2008)

28. Kaszuba JP, Runde WH: The aqueous geochemistry of neptunium: Dynamic control of soluble concentrations with applications to nuclear waste disposal. Environ Sci Technol 1999, 33:4427-4433.

29. Murphy WM, Shock EL: Environmental aqueous geochemistry of actinides. In Uranium: Mineralogy, Geochemistry and the Environment. Reviews in Mineralogy Volume 38. Edited by: Burns PC, Finch R. Mineralogical Society of America, Washington, D.C.; 1999:221-253.

30. Langmuir $D$ : Uranium solution-mineral equilibria at low temperatures with applications to sedimentary ore deposits. Geochim Cosmochim Acta 1978, 42:547-569.

31. Pabalan RT, Turner DR: Uranium(6+) sorption on montmorillonite: Experimental and surface complexation modeling study. Aqu Geochem 1997, 2:203-226.

32. Zielinski RA, Meier A: The association of uranium with organic matter in Holocene peat: An experimental leaching study. Aqu Geochem 1988, 3:631-643.

33. Carroll SA, Bruno J, Petit J-C, Dran J-C: Interactions of $\mathbf{U}(\mathbf{V I}), \mathbf{N d}$, and Th(IV) at the calcite-solution interface. Radiochim Acta 1992, 58/59:245-252.

34. Barnes CE, Cochran JK: Uranium geochemistry in estuarine sediments: Controls on removal and release processes. Geochim Cosmochim Acta 1993, 57:555-569.

35. Wersin P, Hochella MF Jr, Persson P, Redden G, Leckie JO, Harris DW: Interaction between aqueous uranium (VI) and sulfide minerals: Spectroscopic evidence for sorption and reduction. Geochim Cosmochim Acta 1994, 58:2829-2843. 
36. Kalmykov SN, Choppin GR: Mixed $\mathrm{Ca}^{2+} / \mathrm{UO}_{2}{ }^{2+} / \mathrm{CO}_{3}{ }^{2-}$ complex formation at different ionic strengths. Radiochimica Acta 2000, 88:603-606.

37. Lieser KH, Mühlenweg U: Neptunium in the hydrosphere and in the geosphere.I. Chemistry of neptunium in the hydrosphere and sorption of neptunium from groundwaters on sediments under aerobic and anaerobic conditions. Radiochim Acta 1988, 43(I):27-35.

38. Nakata K, Nagasaki S, Tanaka S, Sakamoto Y, Tanaka T, Ogawa H: Sorption and reduction of neptunium (V) on the surface of iron oxides. Radiochim Acta 2002, 90:665-669.

39. Nitsche H, Silva RJ: Investigation of the carbonate complexation of Pu(IV) in aqueous solution. Radiochim Acta 1996, 72:65-72.

40. Choppin GR, Bond AH, Hromadka PM: Redox speciation of plutonium. Journal of Radioanal Nucl Chem 1997, 2 I 9(2):203-2 I0.

4I. Clark DL, Hobart DE, Neu MP: Actinide carbonate complexes and their importance in actinide environmental chemistry. Chem Rev 1995, 95:25-48.

42. Silver GL: Proportional equations in plutonium chemistry. J Radioanal Nucl Chem 2000, 245(2):229-232.

43. Banaszak JE, Rittmann BE, Reed DT: Subsurface interactions of actinide species and microorganisms: Implications for the bioremediation of actinide-organic mixtures. J Radioanal Nucl Chem 1999, 241 (2):385-435.

44. Vaniman DT, Chipera SJ, Bish DL, Carey JW, Levy SS: Quantification of unsaturated-zone alteration and cation exchange in zeolitized tuffs at Yucca Mountain, Nevada, USA. Geochim Cosmochim Acta 200I, 65(20):3409-3433.

45. Bish DL, Vaniman DT, Chipera SJ, Carey JW: The distribution of zeolites and their effects on the performance of a nuclear waste repository at Yucca Mountain, Nevada, USA. Amer Mineral 2003, 88( I |-I 2): |889-1902.

46. Viani B: Formulation of recipes for synthetic J-I3 groundwater that are predicted to be stable at $25^{\circ} \mathrm{C}$ and atmospheric $\mathrm{PCO}_{2}$. Internal report, Lawrence Livermore National Laboratory, Livermore, CA; 2002.

47. Foti SC, Freiling EC: The determination of the oxidation states of tracer uranium, neptunium, and plutonium in aqueous media. Talanta 1964, I I:385-392.

48. Bertrand PA, Choppin GR: Separation of actinides in different oxidation states by solvent extraction. Radiochim Acta 1982, 31:135-137.

49. Nitsche H, Lee SC, Gatti RC: Determination of plutonium oxidation states at trace levels pertinent to nuclear waste disposal. J Nucl Radioanal Chem 1988, I 24(I): I7I-I85.

50. Neu M, Hoffman DC, Roberts KE, Nitsche H, Silva RJ: Comparison of chemical extractions and laser photoacoustic spectroscopy for the determination on plutonium species in nearneutral carbonate solutions. Radiochim Acta 1994, 66/ 67:25I-258.

51. Kobashi A, Choppin GR, Morse JW: A study of the techniques for separating plutonium in different oxidation states. Radiochim Acta 1998, 43:211-215.

52. Brookins DG: Rhenium as analog for fissiogenic technetium: Eh-pH diagram $\left(25^{\circ} \mathrm{C}\right.$, I bar) constraints. Appl Geochem I 986, I:513-5I7.

53. Harvey BR, Williams KJ, Lovett MB, lbbett RD: Determination of technetium-99 in environmental material with rhenium as a yield monitor. J Radioanal Nucl Chem I992, I 58(2):4I7-436.

54. Wharton MJ, Atkins B, Charnock JM, Livens FR, Pattrick RAD, Collins $\mathrm{D}$ : An X-ray absorption spectroscopy study of the coprecipitation of Tc and Re with mackinawite (FeS). Appl Geochem 2000, I 5:347-354.

55. Darab JG, Smith PA: Chemistry of technetium and rhenium species during low-level radioactive waste vitrification. Chem Mater 1996, 8:1004-1021.

56. Richter RC, Koirtyohann SR, Jurisson SS: Determination of technetium-99 in aqueous solutions by inductively coupled plasma mass spectrometry: Effects of chemical form and memory. J Analy Atom Spectro 1997, I 2:557-562.

57. Mas JL, Tagami K, Uchida S: Method for the detection of Tc in seaweed samples coupling the use of $R e$ as a chemical tracer and isotope dilution inductively coupled plasma mass spectrometry. Analytica Chimica Acta 2004, 509(I):83-88
58. ASTM: Standard test method for 24-hour batch-type measurement of contaminant sorption by soils and sediments (D4646-87). In I998 Annual Book of ASTM Standards American Society for Testing and Materials, Philadelphia, PA; 1998:44-47.

59. Komlos J, Kukkadapu RK, Zachara JM, Jaffe PR: Biostimulation of iron reduction and subsequent oxidation of sediment containing Fe-silicates and Fe-oxids: Effect of redox cycling on Fe(III) bioreduction. Water Res 2007, 4I:2996-3004.

60. Nordstrom DK: Thermochemical redox rquilibria of Zobells solution. Geochim Cosmochim Acta 1977, 4 I (1 2): |835- I84|.

61. Lindberg RD, Runnells DD: Groundwater redox reactions: An analysis of equilibrium state applied to Eh measurements and geochemical modeling. Science 1984, 225:925-927.

62. Tanji KK, Gao S, Scardaci SC, Chow AT: Characterizing redox status of paddy soils with incorporated rice straw. Geoderma 2003, I I 4(3-4):333-353.

63. Bartlett RJ: Characterizing soil redox behavior. In Soil Physical Chemistry Edited by: Sparks DL. Boca Raton, FL, CRC Press; 1999:37|-397.

64. Lovley DR, Goodwin S: Hydrogen concentrations as an indicator of the predominant terminal electron-accepting reactions in aquatic sediments. Geochim Cosmochim Acta 1988, 52:2993-3003.

65. Stout DL, Carroll SA: A literature review of actinide-carbonate mineral interaction. Sandia National Laboratories, Albuquerque, NM: SAND92-7328; 1992.

66. Beyenal H, Sani RK, Peyton BM, Dohnalkova AC, Amonette JE, Lewandowski Z: Uranium immobilization by sulfate-reducing biofilms. Environ Sci Technol 2004, 38(7):2067-2074.

67. Hua B, Xu HF, Terry J, Deng BL: Kinetics of uranium(VI) reduction by hydrogen sulfide in anoxic aqueous systems. Environ Sci Technol 2006, 40( I 5):4666-467I.
Publish with Bio Med Central and every scientist can read your work free of charge

"BioMed Central will be the most significant development for disseminating the results of biomedical research in our lifetime. "

Sir Paul Nurse, Cancer Research UK

Your research papers will be:

- available free of charge to the entire biomedical community

- peer reviewed and published immediately upon acceptance

- cited in PubMed and archived on PubMed Central

- yours - you keep the copyright 